Article

\title{
A Glossary of New Testament Narrative Criticism with Illustrations
}

\author{
James L. Resseguie \\ Winebrenner Theological Seminary, Findlay, OH 45840, USA; resseguiej@findlay.edu
}

Received: 10 February 2019; Accepted: 15 March 2019; Published: 21 March 2019

\begin{abstract}
This is the first stand-alone glossary of New Testament narrative-critical terms in the English language. It is an alphabetical listing of prominent terms, concepts, and techniques of narrative criticism with illustrations and cross-references. Commonly used terms are defined and illustrated, these include character, characterization, double entendre, misunderstanding, implied author, implied reader, irony, narrator, point of view, plot, rhetoric, and other constitutive elements of a narrative. Lesser-known terms and concepts are also defined, such as carnivalesque, composite character, defamiliarization, fabula, syuzhet, hybrid character, MacGuffin, masterplot, primacy/recency effect, and type-scene. Major disciplines-for example, narratology, New Criticism, and reader-response criticism - are explained with glances at prominent literary critics/theorists, such as Aristotle, Mikhail Bakhtin, Wayne Booth, Seymour Chatman, Stanley Fish, E. M. Forster, Gérard Genette, Wolfgang Iser, and Susan Sniader Lanser.
\end{abstract}

Keywords: narrative criticism; narratology; literary terms; literary criticism; reader-response criticism; New Criticism; close reading

\section{Introduction}

Narrative criticism focuses on how the New Testament works as literature. The "what" of a narrative (content) and the "how" (rhetoric and structure) are analyzed as a complete tapestry, an organic whole. Narrative critics are concerned primarily with the literariness of New Testament narratives or the qualities that make them literature. It is a shift away from traditional historical-critical methods to how the text communicates meaning as a self-contained unit, an undivided whole. Of the three main components of a literary work-author, text, reader-narrative criticism focuses primarily on the text. It attends to the constitutive features of narratives, such as characterization, setting, plot, literary devices, point of view, narrator, implied author, and implied reader.

The precursors of narrative criticism are Russian formalism, French structuralism, and New Criticism. In 1982, David Rhoads coined the term "narrative criticism" to describe this new literary approach to the Gospel of Mark (Rhoads 1982). Also in 1982, David Rhoads and Donald Michie analyzed Mark from a narrative-critical perspective, focusing specifically on the narrator, point of view, literary technique, setting, plot, and character (Rhoads and Michie 1982). In 1983, R. Alan Culpepper published a groundbreaking narrative-critical study on the Fourth Gospel. Culpepper was influenced by the literary critic Seymour Chatman who explored the narrative dynamics of a text in terms of its story (the content) and its discourse (the how). The influence of Chatman can be seen in Culpepper's opening statement to Anatomy of the Fourth Gospel: "Our aim is to contribute to the understanding of the gospel as a narrative text, what it is and how it works (Culpepper 1983, p. 5). This twofold emphasis on story ("what it is") and discourse ("how it works") became the focus of narrative criticism in its early years. Short articles on narrative criticism introduced readers to the basic concepts and techniques of the new discipline (Malbon 2008; Tull 2013; Resseguie 2013b; Resseguie forthcoming (a) 
"Narrative Criticism/Narratology"). Full length introductions served as readers' guides to narrative criticism (Powell 1990; Marguerat and Bourquin 1999; Tolmie 1999; Resseguie 2005).

Initially, New Testament narrative criticism focused on the four canonical gospels and Acts, but later turned its attention to the narrative features of the book of Revelation (Barr 1998, 2016; Resseguie 1998, 2005, 2009, forthcoming (b) "Narrative Features"). Recently, a plethora of studies on characters and characterization in the gospels and Acts have relied on the insights of narrative criticism and narratology—for example, Rhoads and Syreeni (1999); Malbon (2000, 2009); Elliot (2011); Hunt et al. (2013); Skinner (2013); Skinner and Hauge (2014); and Dicken and Snyder (2016). Initially, narrative criticism relied on formalism and close readings of narrative texts. Today, it has moved beyond formalism and appropriated other approaches to the New Testament. It has examined the politics of the first century world (Horsley 2001; Carter 2004) and the social world of the New Testament (Rhoads 2004), applied feminist criticism to narrative criticism (Anderson 1983; Malbon 1983), incorporated the insights of reader-response criticism to narrative criticism (Powell 2001; Powell 2011; Resseguie 2016), and applied cognitive narratology to New Testament narrative criticism (Hongisto 2010; Green 2016; see Herman 2013).

This is the first stand-alone glossary of New Testament narrative-critical terms in the English language. It is an alphabetical listing of prominent terms, concepts, and techniques of narrative criticism with illustrations and cross-references. Inevitably some terms are missing from the glossary, and some readers may wonder why other terms are included. However, as a short compendium of narrative criticism, it contains many of the major terms, concepts, and techniques of New Testament narrative criticism. (Although this is the first stand-alone glossary of New Testament narrative criticism, Daniel Marguerat and Yvan Bourquin have an abbreviated glossary at the end of their introduction to narrative criticism (Marguerat and Bourquin 1999, pp. 173-78). Janice Capel Anderson and Stephen D. Moore also provide a glossary at the end of their introduction, Mark and Method (Anderson and Moore 2008, pp. 233-43).)

\section{A Glossary of New Testament Narrative Criticism ${ }^{1}$}

affective fallacy $\rightarrow$ New Criticism.

alazon $\rightarrow$ character.

ambiguity $\rightarrow$ double entendre and misunderstanding.

anagnorisis ("recognition") $\rightarrow$ plot and type-scene.

anaphora: "Anaphora" is the repetition of the same expression at the beginning of two or more successive clauses or sentences to add force to an argument. For example, the writer of the book of Hebrews reiterates the word "by faith" at the beginning of sentences to foreground a theological perspective:

By faith we understand...

by faith Abel ...

by faith Noah...

by faith Abraham ...

by faith Isaac...

by faith Jacob ...

by faith Joseph ...

by faith Moses...

1 All the terms in this glossary are in alphabetical order and in boldface. Any term that is not itself the subject of an entry is also in boldface with a cross-reference to an entry where it is discussed. 
by faith the people passed through the Red Sea...

by faith the walls of Jericho fell ...

by faith Rahab ... (Hebrews 11). ${ }^{2}$

In Matthew 13, the gospel writer introduces a series of parables with the anaphoric phrase "the kingdom of heaven is like":

The kingdom of heaven is like a mustard seed ...

The kingdom of heaven is like yeast...

The kingdom of heaven is like treasure hidden in a field ...

The kingdom of heaven is like a merchant...

The kingdom of heaven is like a net... (Matt. 13: 31, 33, 44, 45, 47).

antagonist $\rightarrow$ character.

antithesis $\rightarrow$ parallelism.

aside $\rightarrow$ characterization.

carnivalesque: "Carnivalesque" is a term coined by Mikhail Bakhtin to describe the upside-down world of carnival. As a literary device, carnivalesque flouts conventions of authority and inverts social hierarchies of the existing culture. It expresses "life drawn out of its usual rut" and "the reverse side of the world ('monde à l'envers')" in which normally suppressed voices of the culture mock everyday social hierarchies and the voices of the status quo (Bakhtin 1984, p. 122). Bakhtin identifies four basic categories that characterize carnivalesque.

(1) The laws, prohibitions, restrictions, and hierarchical structures that are associated with everyday life are suspended in carnival. As a result, "a special carnival category goes into effect: free and familiar contact among people" (Bakhtin 1984, p. 123, emphasis Bakhtin).

(2) The latent sides of human nature reveal and express themselves in carnival. "The behavior, gesture, and discourse of a person are freed from the authority of all hierarchical positions (social estate, rank, age, property)" (Bakhtin 1984, p. 123). The everyday is overturned in favor of an inside-out world.

(3) Carnival combines "the sacred with the profane, the lofty with the low, the great with the insignificant, the wise with the stupid" (Bakhtin 1984, p. 123).

(4) The last of Bakhtin's carnivalistic categories is profanation. Blasphemy, mocking, and deriding are common acts of debasing during carnival.

The primary act of carnival is the mock crowning and subsequent de-crowning of a carnival king. It is a "dualistic ambivalent ritual" that typifies the inside-out world of carnival and the "joyful relativity of all structure and order" (Bakhtin 1984, p. 124, emphasis Bakhtin). In carnival, the one who is crowned is the opposite of a real king (a slave or jester), and the symbols of crown, scepter, and robe that symbolize structures of authority in the ordinary world take on new meaning in carnival's mock ritual. They become "almost stage props" that undermine the "heavy" and "serious" structures of the everyday world (Bakhtin 1984, p. 124). But coronation is incomplete without de-coronation: regal vestments are stripped off, the crown and scepter are removed, and the mock king is beaten. Although de-coronation appears to be "naked, absolute negation and destruction," it is actually a positive image of "constructive death" (Bakhtin 1984, p. 125).

2 All scriptural references, unless otherwise noted, are from the New Revised Standard Version (NRSV). 
The passion narrative of the First Gospel is imbued with the carnivalesque (Matt. 27:27-31). The soldier's investiture of the mock king emphasizes the "joyful relativity" of all structures and order. They place a scepter (reed) in Jesus's right hand and kneel before him in scornful honor (Matt. 27:29). Their gallows humor is a form of carnivalistic laughter that heightens both the dualistic and ambivalent symbols of this mock ritual. The gentile soldiers deride Jesus as "King of the Jews" (Matt. 27:29), but their carnivalistic laughter turns out to be true: Jesus is indeed "King of the Jews". De-crowning completes the act of mock coronation. Jesus's royal cloak and scepter are taken away and his own clothes are put on. The crowning and de-crowning appears to be absolute negation: jeering, abuse, spitting, and mockery of an imposter. But the celebration of negativity has a positive side. Jesus inaugurates a new kind of order, a different type of rule in which the old ways of structuring this world are shattered and are replaced with a new kind of kingship.

catastrophe $\rightarrow$ plot.

character: "Characters" are the dramatis personae-the persons in the story-who may be major or minor characters that play a role in the plot. The protagonist or hero is the chief character in the plot around whom the action centers. An antagonist is a rival or opponent of the protagonist. In the gospels, Jesus is the protagonist while the religious authorities are often pitted against him as the antagonists. Flat and round characters are terms used by E. M. Forster in Aspects of the Novel (Forster [1927] 2005) to describe character types. A flat character is a two-dimensional character constructed around a single idea or quality that is summed up in a single phrase or sentence. A round character is three-dimensional and possesses several complex traits. "The test of a round character is whether it is capable of surprising in a convincing way. If it never surprises, it is flat. If it does not convince, it is flat pretending to be round" (Forster [1927] 2005, p. 81). For example, Jesus and the disciples are round characters with complex and-in the case of the disciples-conflicting traits. The Pharisees, on the other hand, are flat characters that lack complexity and exhibit a single trait of duplicity or obstructiveness. As individuals, however, the Pharisees are complex and surprising (e.g., Nicodemus in John 3; Saul/Paul in Acts). Identifying a character as flat or round is not as important as identifying the singular traits that make a character complex and surprising, or unconvincing and predictable.

Flat and round characters can either be dynamic (developing) or stati (un-developing).c Dynamic characters undergo change throughout the course of a narrative, displaying new behaviors and changed outlooks and can step outside the bounds of the narrative. "The change may be a large or a small one; it may be positive or negative; but it is something significant and basic, not some minor change of habit or opinion" (Arp and Johnson 2017, p. 107). A dynamic character-or what Thomas Docherty calls kinetic character-is capable of being absent from the text. "This character's motivation extends beyond that which is merely necessary for the accomplishment of the design of the plot, and he or she 'moves' in other spheres than the one we are engaged in reading" (Docherty 1983, p. 224). On the other hand, static characters are cardboard figures that do not develop or change and cannot step outside the bounds of the narrative. They are simply a function of the plot (Docherty 1983, p. 224). Generally, round characters are dynamic and flat characters are static. But as Shlomith Rimmon-Kenan notes in Narrative Fiction, round characters can be complex yet un-developing and flat characters can be simple yet developing (Rimmon-Kenan 2002, pp. 40-41). The importance of plotting the development of a dynamic character cannot be underestimated. According to Laurence Perrine, the "change [in a character] is usually at the heart of the story and defining and explaining the change will be the best way to arrive at its meaning" (Arp and Johnson 2017, p. 107).

Other character types include stock, composite character, foil, walk-on, and hybrid character. A stock character is a type that appears repeatedly in narratives and is recognized as part of the conventions of a literary genre. In fairy tales, the cruel stepmother and the charming prince are stock characters (Harmon 2012, p. 456). In film noirs, the femme fatale, an attractive yet dangerous woman, is a stock character of this genre. In ancient Greek comedy, the eiron is a stock character along with its opposite type, the alazon. The eiron pretends to know less than he knows and speaks in understatement, while the alazon is the braggart who claims to know more than he knows. In John 9, 
the exchange between the man born blind and the religious leaders is a classic example of an eiron dissembling the boastful claims of an alazon. Although the religious authorities revile the man born blind and call him a man "born entirely in sins" (John 9:34), the healed man gains the upper hand by feigning ignorance: "Do you also want to become his disciples?" (John 9:27c). Then he lectures the learned authorities on basic theology:

We know that God does not listen to sinners, but he does listen to one who worships him and obeys his will. Never since the world began has it been heard that anyone opened the eyes of a person born blind (John 9:31-32).

On the eiron-character type, see Whitenton (2016).

A composite character is similar to a stock character. But the term designates two or more historical figures that are construed as a single character. For example, Luke's development of the three Herods in the gospel and Acts-Herod the Great, Herod Antipas, and Herod Agrippa I-are historical rulers whose traits have merged to form a single composite character. Frank Dicken has shown that this "Herod" is an amalgamation of rulers who function in the narrative as "an actualization of Satan's desire to impede the spread of the good news though his ["Herod's"] rejection of the gospel message and through political persecution", for example the execution of John (Luke 9:7-9), Jesus (Acts 4:24-28), James (Acts 12:1-2), and the attempted execution of Peter (Acts 12:3-5) (Dicken 2014, p. 7). Pharaoh is also a composite/stock character who functions as an opponent and persecutor of the people of God. He appears at the exodus of the Israelites out of Egypt (cf. Exodus 14-15), re-appears in Matthew's Gospel as Herod (the Great) who seeks to destroy Israel's new Moses (cf. Matt. 2:1-18), and appears once more in Revelation as the "great dragon" or "ancient serpent" who pursues and persecutes the people of God on their journey to the new promised land, the new Jerusalem (cf. Rev. 12: 13-17).

A foil is literally a contrasting background such as a sheet of shiny metal that is placed under jewels to enhance their brilliance. In literature, a foil is a character that enhances the distinctive characteristics of another character through contrast (Harmon 2012, p. 202). For example, the wealthy who contribute out of their abundance are foils for the poor widow who puts into the treasury far less but gives far more (Mark 12:41-44; Luke 21:1-4). Narrative settings can contrast with each other and thus serve as foils. For example, Babylon, a city of oppression and exploitation, contrasts with the new Jerusalem, a city of abundance and perfection (Rev. 18 and 21-22). The throne on which Jesus is crucified and exalted — the cross—contrasts with the opulent throne of earthly rulers.

Walk-on is a term used by Seymour Chatman for characters that are not fully delineated and individualized but are "mere elements of the setting" (Chatman 1978, p. 139). They do not qualify as characters—even as stock characters—but are part of the background. Yet they can play an important role as human barricades or grumblers that voice conventional societal norms. For example, the crowd in Luke 19:1-10 is an immoveable barrier to Zacchaeus's quest to see Jesus, underscoring not only the difficulty of the tax collector's quest but also his resolve (19:3). Also, the crowd functions like an ancient Greek chorus that provides commentary and perspective on characters and the meaning of their actions. They voice the conventional religious and social attitudes of the first century. "He [Jesus] has gone to be the guest of one who is a sinner" (Luke 19:7). Roman soldiers are also walk-ons-faceless and nameless characters of the crucifixion that are necessary for the story but are seldom delineated. (An exception is the centurion of Luke 23:47 who is individualized — that is, given a voice-and is a foil to the authorities that condemned Jesus to death.)

A hybrid character blends characteristic of humans with the inhuman or the monstrous with human traits. Examples of mythological hybrids include the centaur with the face, arms, and trunk of a human and the body of a horse; the Greek sphinx with the face of a woman and the body of a lion with wings; and the manticore with the head of a man and three rows of teeth, the body of a lion, and a scorpion-like or dragon tail. Hybrid characters represent the divided and conflicted nature of humanity. For example, the centaur depicts the unbridled and uncontrollable side of humanity. The Greek sphinx represents the cunning, trickster nature of humans. In Sophocles' Oedipus narratives the 
sphinx devoured all who could not answer its puzzling riddle: "What is the creature that walks on four legs in the morning, two legs at noon, and three legs in the evening." Oedipus correctly answers the riddle (it is a human) and the sphinx throws herself to death. The manticore with its monstrous appearance and shark-like teeth represents the bestial or vicious trait of human beings.

Hybrid characters are also found in biblical literature, most notably the bizarre characters of the book of Revelation. The evil hybrids of Revelation are the locusts from the abyss (Rev. 9:3-11), the beast from the sea (Rev. 11:7; 13:1-10, 18; 17:8), and the beast from the land (Rev. 13:11-17; 16:13; 19:20; 20:10). For example, the locusts from the abyss combine human traits with monstrous characteristics: faces like human faces, hair like woman's hair, teeth like lions' teeth, and tails like scorpion tails. The merger of the human with the inhuman represents the collusion of the world below with this world in Revelation's three-part universe (the world above, this world, and the world below). They signify a world turned upside down and inside out and exemplify what the world would be like if God gave free and unrestrained reign to evil. The beast from the sea combines animal traits (leopard, bear, lion) with human characteristics (a human number, 666, in Rev. 13:18), and the beast from the land has two horns like a lamb yet is clearly human (Rev. 13:11).

Other hybrids of Revelation are of a different sort. The four living creatures in Rev. 4:6b-8 combine traits of the world above (six wings; eyes in front and behind and around and inside) with animal and human traits from this world (lion, ox, eagle, and human). Whereas the locusts represent this world torn asunder, the four living creatures depict a world in complete harmony with its Creator (Resseguie forthcoming (b) "Narrative Features").

characterization: Two commonly recognized methods for the presentation of characters are showing (also called dramatic method or indirect presentation) and telling (also called direct presentation). In showing, the author or narrator presents the characters talking and acting from which the reader infers character traits and motives. According to Seymour Chatman, a character trait is the minimal persistent quality of a character that enables the reader to distinguish one character from another (Chatman 1978, pp. 121-26). In showing, character traits are revealed through speech, actions, clothing, physical description, posture, affect, gender, and socio-economic status (Dinkler 2017, pp. 691-92). What characters say, what they wear, what they do, how they relate to others, and how they appear, reveal defining traits (Resseguie 2005, p. 121; Resseguie 2009, pp. 38-39). What others say about them and how they respond enhance characterization. In addition, literary foils amplify character traits while symbolic settings magnify characters' speech and actions. Michal Beth Dinkler has shown how silence-what is unsaid in the telling of a tale, including gaps and ambiguities-provides a window into a character's traits (Dinkler 2013). In Luke 7:36-50, the uninvited, unnamed woman is silent, yet her symbolic action speaks: "she honors Jesus as she anoints him" (Dinkler 2013, p. 122). Jesus also embraces silence in this scene when he accepts her actions and behavior without comment, setting the stage for conflict with the host, Simon the Pharisee.

Interior monologue (also called an unspoken soliloquy) is a conspicuous method of showing a character's traits. It is a "species of stream of consciousness which undertakes to present to the reader the course and rhythm of consciousness precisely as it occurs in a character's mind" (Abrams and Harpham 2015, p. 379). Robert Scholes and Robert Kellogg define interior monologue as "a direct, immediate presentation of the unspoken thoughts of a character without any intervening narrator" (Scholes et al. 2006, p. 177). Interior monologues in the gospels provide a glimpse into a character's motivations, thinking, and Weltanschauung (worldview). Philip Sellew and Michal Beth Dinkler offer several examples of interior monologues in Luke's parables (Sellew 1992; Dinkler 2015). For example, the rich farmer's self-talk in Luke 12:16-20 reveals a tragic flaw of hubris:

"What should I do, for I have no place to store my crops?" Then he said, "I will do this: I will pull down my barns and build larger ones, and there I will store my grain and my goods. And I will say to my soul, "Soul, you have ample goods laid up for many years; relax, eat, drink, be merry" (Luke 12:17b-19). 
An unspoken soliloquy in Luke 7:39 reveals not only Simon the Pharisee's point of view; it educates the reader on the cultural and religious perspectives of the first century. "If this man [Jesus] were a prophet, he would have known who and what kind of woman this is who is touching him-that she is a sinner." (Interior monologues are also found at Luke 12:42-46; 15:11-32; 16:1-8; 18:2-5; 20:9-16.)

An author/narrator also uses names and epithets to amplify character traits. Proper names are "saturated with meaning" and are prominent ways of highlighting characteristics (Hochman 1985, p. 37). For example, the character named Abaddon in Revelation means "destruction" (9:11), Apollyon means "Destroyer" (9:11), and the beast's name in 13:18 is a number saturated with meaning. In Mark 5:1-20, the foreign possessing power of the demoniac is called "Legion." Names-whether an expanded name or a shortened, personal name-mark seminal moments in a narrative and accent a character's development. The story of Mary Magdalene in John 20:1-18 is an example of the use of a personal name at a crucial point to heighten the importance of a discovery. The narrator uses Mary's full name-Mary Magdalene—as bookends of the narrative (John 20:1, 18). Then he shortens her name to "Mary" (John 20:11); meanwhile, the angels and Jesus address her as "woman" in their encounter with Mary (John 20:13, 15). But when the veil of incomprehension is lifted, and she recognizes the risen Jesus, both her formal name and the generic - "woman" - are cast aside, and she is called by her personal name "Mary" (John 20:16).

In the Fourth Gospel, Peter's priority as the first disciple who enters the empty tomb is marked by an expansion of his name. In John 20:2-10, Peter is introduced into the narrative with his full name, "Simon Peter" (John 20:2), which is the normal way the disciple is mentioned at the outset (Elliott 1972). Then the narrator shortens his name to "Peter" twice (in 20:3 and 20:4), which is the usual way of referring to him after the formal introduction. But at the crucial moment of discovery-when he enters the tomb and sees the linen wrappings and the soudarion rolled up by itself-the narrator discards the shortened name. He does not say, "Peter ... went into the tomb," as might be expected. Rather, the narrator lengthens his name to call attention to the discovery and Peter's priority: "Simon Peter ... went into the tomb" (John 20:6-7; Resseguie 2001, p. 150 n. 135). On names see Docherty (1983, chp. 2); Dawsey (1986, pp. 143-47).

An epithet is an adjective or adjectival phrase that describes a character's distinctive quality. In Revelation, John uses no less than five sobriquets or epithets to define Satan's character: “The great dragon ... that ancient serpent, who is called the Devil and Satan, the deceiver of the whole world ... was thrown down to earth" (Rev. 12:9). In the Fourth Gospel, an unnamed character is given a descriptive phrase not only to underline his unique relationship to Jesus (cf. John 13:25); it underscores his singular trait of privilege that enables him to "see" what other disciples cannot "see" (e.g., John 20:8; 21:7). This disciple—“"the one whom Jesus loved" (John 13:23-26; 19:26-27; 20:2-10; 21:7, 20-23)—represents the ideal point of view of the gospel, the ideological perspective that John wants the reader to embrace (Resseguie 2013a, 2016).

An expanded description can alert the reader to a striking development in a narrative. A case in point are the descriptions given to the beloved disciple in John 20:2-9. The anonymous disciple is introduced with his traditional, identifying marker: "the other disciple, the one whom Jesus loved" (John 20:2). Afterwards, "the one whom Jesus loved" is dropped and the beloved disciple is referred to as "the other disciple" (John 20:3, 4). But the abbreviated designation, "the other disciple," is expanded at a key moment in the narrative: "Then the other disciple, who reached the tomb first, also went in, and he saw and believed" (John 20:8). Although Peter is the first to enter and see the discarded garments in the tomb, the beloved disciple is the first to reach the tomb and to interpret the significance of the abandoned grave clothes.

In telling, the narrator intervenes and adds authoritative comments on characters and their disposition. An omniscient/intrusive narrator-one who sees all and comments on what he or she sees-can peer into a character's mind and reveal his or her thinking, feelings, and motives (also called inside view). A narrator may also provide commentary on characters or events that gives the reader/hearer information that may or may not be available to the characters in the story. This 
commentary is called an aside (Rhoads et al. 2012, pp. 42-43; Sheeley 1992). For example, the narrator of Acts provides important information to the reader on the beliefs of the Sadducees and Pharisees through an aside: "The Sadducees say there is no resurrection, or angel, or spirit; but the Pharisees acknowledge all three" (Acts 23:8). (The NRSV puts this verse in parenthesis to show that it is an intrusive comment.) Whenever the narrator relies on telling, the reader does not need to infer the attributes of a character from what the character says or does. Rather the narrator provides information about a character's traits and motivations.

Other aspects of telling go beyond basic information and delve into a character's motivations and thinking. The narrator may also provide an evaluation or judgment concerning the character. For example, the disciples "did not understand about the loaves, but their hearts were hardened" (Mark 6:52). The phrase "their hearts were hardened" is the narrator's evaluation of the disciples' blindness. In the Fourth Gospel, the narrator tells the reader what to anticipate and how to evaluate an antagonist and his words. For example, when Judas is first introduced, the narrator adds this comment: Judas "was going to betray [Jesus]" (John 6:71). Later, when Judas complains about an expensive perfume that was used to anoint Jesus-an extravagance that he claims should have been used to help the poor-the narrator intervenes. He explains not only Judas's motive for the complaint; he also reveals a disqualifying trait that was previously unknown to the reader. "He said this not because he cared about the poor, but because he was a thief; he kept the common purse and used to steal what was put into it" (John 12:6). Because inside views are taken as authoritative comments by a reliable narrator-one that shares the perspective of the implied author-they influence how the reader reads the narrative, evaluates characters, and understands the ideological norms and beliefs of the narrative. (The opposite of a reliable narrator is an unreliable or fallible narrator, who does not share the perception, interpretation, and evaluation of the implied author. Although an unreliable narrator occurs in modern literature, he or she is unknown in New Testament literature.) On reliable and unreliable narrators see Booth (1983, pp. 158-59), and on the concept of unreliability see Shen (2013).

chiasmus (chiasm): "Chiasmus" or "chiasm" is derived from the Greek letter chi (written X). An X symbolizes the crossover pattern of words, phrases, clauses, or ideas that are repeated in reversed order. The simplest type of chiasmus is an A B B' A $^{\prime}$ pattern as seen in Mark 2:27:

The sabbath was made (A)

for humankind (B),

and not humankind (B')

for the sabbath $\left(\mathrm{A}^{\prime}\right)$.

In Luke 22:42, a chiasm illustrates the conflict Jesus has within himself concerning his mission and his desire to follow the Father's will:

Father, if you are willing (A),

remove this cup from me $(\mathrm{B})$;

yet, not my will (B')

yours be done $\left(\mathrm{A}^{\prime}\right)$.

The first person singular (me, my) is placed within the second singular (you, yours), which underscores Jesus' resolve: his will is completely enclosed in the Father's will.

The writer of Ephesians uses a chiasmus of grace and peace to bracket the entire book:

Grace to you (A)

and peace ... (B) (Ephesians 1:2). 
Peace $\left(B^{\prime}\right) \ldots$

Grace $\left(\mathrm{A}^{\prime}\right) \ldots$ (Ephesians 6:23, 24).

And Paul uses an interlocking chiasmus to highlight the mystery of the Christian faith in 1 Timothy 3:16. Two worlds - the world above (spirit, angels, glory) and this world (flesh, Gentiles, world), which were separated or at odds with one another at the beginning, are joined together by the life, mission, and death of Jesus (Resseguie 2000, p. 817; Resseguie 2005, p. 60).

[Jesus] was revealed in flesh (A),

vindicated in spirit (B),

seen by angels $\left(B^{\prime}\right)$,

proclaimed among Gentiles ( $\left.\mathrm{A}^{\prime}\right)$,

believed in throughout the world (A),

taken up in glory (B).

The first chiasm $\left(\mathrm{A}, \mathrm{B}, \mathrm{B}^{\prime}, \mathrm{A}^{\prime}\right)$ interlocks with the second $\left(\mathrm{B}^{\prime}, \mathrm{A}^{\prime}, \mathrm{A}, \mathrm{B}\right)$, as the following diagram illustrates:

flesh (A)

spirit (B)

angels $\left(\mathrm{B}^{\prime}\right)$

Gentiles (A').

angels $\left(\mathrm{B}^{\prime}\right)$

Gentiles $\left(A^{\prime}\right)$

world (A)

glory (B).

close reading $\rightarrow$ New Criticism.

composite character $\rightarrow$ character.

defamiliarization: The Russian formalist Victor Shklovsky coined and popularized the concept of defamiliarization (ostranenie, which literally means "making strange") in his article "Art as Technique" (Shklovsky [1917] 2012). (The concept precedes Shklovsky and is found at least as early as the Romantic critic Coleridge [1817] 1983). Defamiliarization-also called estrangement-is the creative distortion of the world of ordinary perception to renew the reader's diminished capacity for fresh awareness. Everyday language leads to over-automatization or automatic perception that results in a stale view of the world. Defamiliarization jars the reader out of the lethargy of the habitual and forces the reader to see the world anew. The reader's renewed mode of perception is achieved through literary devices or techniques that disrupt automatic perception-slowing down the reading process so that the familiar no longer seems familiar. Shklovsky provides several examples of defamiliarization techniques: a novel point of view, the substitution of the unexpected for the expected, a subtle twisting of a commonplace phrase, and the deformation of a familiar context (Shklovsky [1917] 2012; Resseguie $1988,1990,1991)$. The process of "making strange" forces the reader to view worn-out rhetoric, familiar contexts, stereotyped phrases, and jaded conventions in unfamiliar ways.

Defamiliarization occurs wherever language and conventions are deformed. In Mark, a jarring phrase—“with persecutions" — gives the hearers (disciples) and readers pause: 
Jesus said, "Truly I tell you, there is no one who has left house or brothers or sisters or mother or father or children or fields, for my sake and for the sake of the good news, who will not receive a hundredfold now in this age-houses, brothers and sisters, mothers and children, and fields with persecutions — and in the age to come eternal life" (Mark 10:29-30).

Initially the saying confirms the disciples' decision to follow Jesus-for loss is gain and what is left behind will be multiplied many times over. The expectation is established by first listing the family members and possessions that have been left behind: "house or brothers or sisters or mother or father or children or fields." It is then reinforced by listing what is gained in the plural: "houses and brothers and sisters and mothers and children and fields" (author's translation). The repetition of what is left behind along with what is gained creates in the reader what E. H. Gombrich calls the "etc. principle"-that is, "the assumption we tend to make ... that to see a few members of a series is to see them all" (Gombrich 1961, p. 220). With the reader's expectations firmly established, Mark shatters them with the unexpected phrase "with persecutions". Not only is the phrase surprising; it appears out of place in a saying intended to encourage the disciples in their decision to follow Jesus. Matthew and Luke, who are likely dependent on Mark, removed the offending words from their accounts (cf. Matt. 19:29; Luke 18:29-30).

The Russian formalists also recognized that a plot defamiliarizes a story. They used the terms fabula and syuzhet to differentiate between story and plot. The fabula is the basic story stuff of a narrative while the syuzhet is the representation of that story stuff as a concrete plot. A story can be made unfamiliar by its reformulation into a plot with jarring twists, omissions, digressions, and postponement of important information. In other words, the syuzhet is the fabula defamiliarized. Shklovsky uses Lawrence Sterne's Tristram Shandy as an example of a story that is deformed when it is reformulated into a concrete plot. The normal temporal-causal sequence of narrated events (the familiar way) is disrupted when reshaped into a plot that distorts the story (the unfamiliar way). Temporal displacements, digressions, and causal disruptions (e.g., placing the effects before their causes) impede the reader's ability to reassemble the story, and thus what may appear as a familiar story is upended by unfamiliar plotting. The defamiliarized plot causes the reader to pay attention and to see the story in a new, unjaded way. Similarly, a story within a gospel can be made more forceful by the temporal displacement of relevant information. The plot (syuzhet) of Luke 7:36-50 omits important information at the beginning and places it later, after the reader's expectations and judgments are firmly established (Resseguie 1991, pp. 145-46; Resseguie 2016, pp. 18-19). The chronological storyline (fabula) of Luke 7:36-50 is as follows:

(1) Simon invites Jesus to a dinner party.

(2) But the Pharisee omits acts of hospitality.

(3) An uninvited woman crashes the party and anoints and washes Jesus's feet.

(4) Simon demurs.

(5) Jesus tells a parable.

(6) He contrasts the woman's behavior with the Pharisee's negligence.

(7) Jesus pronounces the woman forgiven of her sins.

This is the story, but it is not the plot. The information in (2) - Simon's omission of acts of hospitality-is only revealed to the reader at (6). By a temporal displacement of crucial and damaging information concerning the Pharisee, the syuzhet (plot) "makes strange" Simon's behavior as well as first-century religious views concerning boundaries between "righteous" and "sinner" (Resseguie 1992, 2016, pp. 7-22).

dénouement (resolution) $\rightarrow$ plot.

direct presentation $\rightarrow$ characterization.

double entendre and misunderstanding: A "double entendre" or double meaning is a word or phrase that is ambiguous, usually having two meanings, and the reader/hearer must choose one meaning and 
reject the other. For example, katalambanein in the Prologue of John is a double entendre that can mean "understand" or "overcome" (John 1:5). The King James Version translates it as "comprehend": "The light shines in the darkness, and the darkness does not comprehend it". On the other hand, the New Revised Standard Version understands it in the second sense: "The light shines in the darkness, and the darkness did not overcome it". In this instance, both meanings are intended, although translators are obliged to choose one meaning over the other. Darkness is not only uncomprehending of light; it is hostile to the light (Barrett 1978, pp. 158-59). Another double entendre is found in Nicodemus' confusion over anōthen which means "again" or "from above" (John 3:3). Did Jesus tell Nicodemus that "no one can see the kingdom of God without being born from above?" or did he say that "no one can see the kingdom of God without being born again?". Nicodemus assumes that Jesus is talking about a physical rebirth. "How can anyone be born after having grown old? Can one enter a second time into the mother's womb and be born?" (John 3:4). Jesus, however, is speaking about a birth from above, a spiritual rebirth (John 3:5-7).

A "misunderstanding" occurs when a double entendre, an ambiguous statement, or an ambiguous metaphor, is misinterpreted. The misunderstanding is then resolved either by Jesus or the narrator. J. H. Bernard offers a simple definition: "A saying of deep import is uttered by Jesus; His hearers misunderstand it, after a fashion that seems stupid; and then He repeats the saying in a slightly different form before He explains it and draws out its lesson" (Bernard 1929, 1: cxi). A misunderstanding occurs when a hearer selects one meaning for a double entendre or ambiguous metaphor rather than another, and assumes that meaning is correct (Bultmann 1971, 135n 1). Alan Culpepper identifies three parts to a misunderstanding in the Fourth Gospel (Culpepper 1983, p. 152).

(1) Jesus makes a claim using a double entendre or an ambiguous metaphor.

(2) The hearer selects one meaning for the statement over another possible meaning. Usually the hearer selects a literal meaning when Jesus intends a figurative meaning.

(3) Jesus or the narrator clarifies the misunderstanding with an explanation.

An illustration of a misunderstanding in John is found in the story of the woman at the well in John 4, which relies on an ambiguous metaphor "living water" (hydōr zōn). In part 1, Jesus asks a Samaritan woman for a drink of water, but she wonders why a Jew is asking a Samaritan for a drink. Jesus responds with a statement built on the ambiguous metaphor "living water": "If you knew the gift of God, and who it is that is saying to you, 'Give me a drink,' you would have asked him, and he would have given you living water" (John 4:10). In part 2, the woman assumes that Jesus knows about a flowing stream - one possible meaning of "living water" - that will make the fetching of water easier. "Sir, you have no bucket, and the well is deep. Where do you get that living water?" (John 4:11). In part 3, Jesus explains that the living water he provides is spiritual, not literal. "Everyone who drinks of this water [from the well] will be thirsty again, but those who drink of the water that I will give them will never be thirsty" (John 4:13-14).

One of the values of analyzing John's rhetorical devices is that it teaches the implied reader how to read (or the authorial audience, see Rabinowitz 1987). Specifically, a misunderstanding teaches the implied reader to move from a reading at the surface level to a deeper level. A surface reading sees only the everyday, the quotidian, the ordinary-just as the woman at the well understood "living water" at a physical, mundane level. Yet to read and to understand at this level is insufficient. The implied author wants the reader to move from the surface to a deeper, spiritual understanding.

Other misunderstandings in John include: 2:19-22, the hearers misunderstand the meaning of the temple; 4:31-34, the disciples misunderstand the nature of Jesus's "food"; $6: 32-35 ; 41-42$, the hearers misunderstand Jesus's origins; $6: 51-53$, the audience misunderstands what Jesus means by bread from heaven; 7:33-36, the Jews misunderstand what Jesus means by his departure; 8:31-33, the hearers misunderstand what Jesus means by freedom; 8:51-53, the audience misunderstands Jesus's claim about those who believe in him will not die, and 8:56-58, they misunderstand the saying about Abraham. 
Misunderstandings also occur in the synoptic gospels-for example, the disciples do not understand about the "loaves," for their "hearts were hardened" (Mark 6:52). However, the synoptic misunderstandings do not rise to the level of a literary device such as that found in the Fourth Gospel.

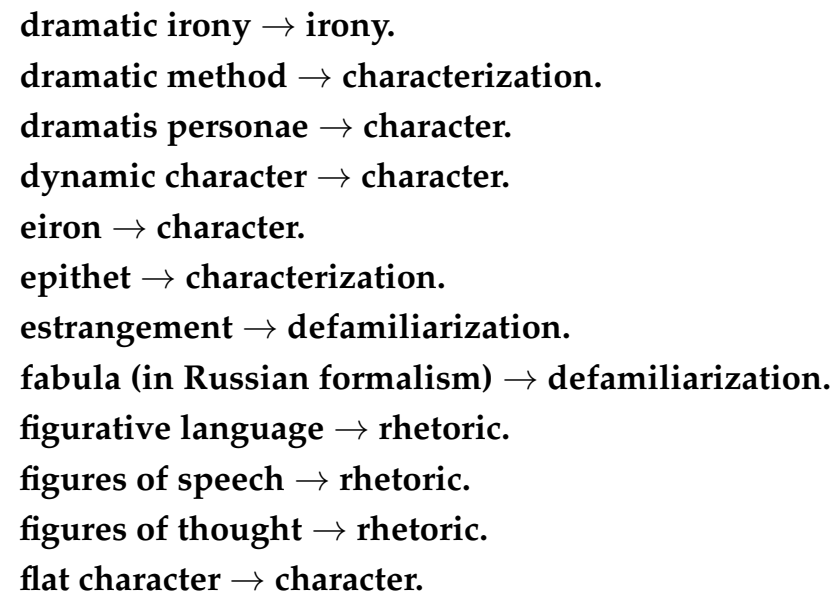

focalization: "Focalization" is a term coined by Gérard Genette [1972] (1980) that is intended to refine point of view and narrative perspective. It asks two primary questions: "Who sees?" and "Who speaks?" in a narrative (Genette [1972] 1980, p. 186; Bal 2009, p. 146). The one who sees the events and happenings of the narrative-called focus of character-may be the same or different from the one who tells the story-called focus of narration. If the narrator chooses to relate events and happenings through the perspective of a character, the character is the one who sees the events of a narrative, but the narrator is the one who speaks. In John 6:19, the disciples of Jesus see what is happening. "They saw Jesus walking on the sea and coming near the boat, and they were terrified". The narrator records the events through the perspective of the disciples, including their emotional response, but the disciples do not tell the story. In Revelation, John, the prophet, who is exiled on the island of Patmos, sees and tells the events and happenings of the narrative. (In technical terms, he is both the focalizer, the one who sees, and the narrator, the one who tells). Although focalization attempts to refine and replace point of view, it is not superior to the concept of point of view. The Living Handbook of Narratology concludes that focalization is "fraught with considerable problems" and is "hardly so much superior to point of view that the old term [point of view] can be discarded" (Niederhoff 2013a). For more on focalization see Bal (2009, pp. 145-65) and Niederhoff (2013a).

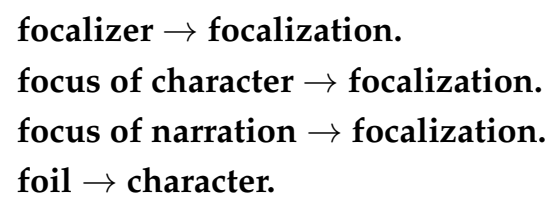

framing device: As the term implies, "framing devices" are words, phrases, and even entire narratives that serve as brackets or bookends for individual narratives or entire books. The framing devices discussed in this glossary are chiasmus, inclusion (inclusio), and sandwich narrative or intercalation.

Freytag's Pyramid $\rightarrow$ plot.

hamartia ("error" or "mistake of judgment") $\rightarrow$ plot.

hubris ("pride") $\rightarrow$ plot.

hybrid character $\rightarrow$ character.

implicit metaphor $\rightarrow$ simile and metaphor.

implied author $\rightarrow$ reader.

implied reader $\rightarrow$ reader and reader-response criticism. 
inclusion (inclusio): "Inclusions" are words, phrases, or concepts that bracket narratives or larger units such as a section of a book or even an entire book. This is a framing device that identifies beginnings and endings of narratives or amplifies prominent themes and concepts of a story. For example, Matt. 1:23 opens with "Emmanuel," which means "God is with us," and closes with Jesus's saying, "I am with you always" (Matt. 28:20). In the book of Revelation, God's pronouncements are bookends for the narrative: "I am the Alpha and Omega" (Rev. 1:8) and "I am the Alpha and Omega, the beginning and the end" (Rev. 21:6). Similarly, Jesus's speech brackets the book with words nearly identical to those of God: "I am the first and the last" (Rev. 1:17) and "I am the Alpha and Omega, the first and the last, the beginning and the end" (Rev. 22:13). As these examples illustrate, inclusions underscore prominent theological themes.

Individual narratives may also be bracketed by words, phrases, and concepts that help identify the structure of a narrative as well as its themes. For example, Matthew's genealogy opens and closes with references to the Messiah, David, and Abraham (Matt. 1:1; 1:17). Within the inclusion are additional brackets that divide the genealogy into three sections of fourteen generations. As a result, Jesus's birth is placed within the entire sweep of Israel's history, and the inclusion amplifies prominent christological titles of the gospel.

indirect presentation $\rightarrow$ characterization.

inside view $\rightarrow$ characterization and point of view/narrative perspective. intentional fallacy $\rightarrow$ New Criticism.

intercalation $\rightarrow$ sandwich narrative.

interior monologue $\rightarrow$ characterization and point of view/narrative perspective. intrusive narrator $\rightarrow$ narrator.

irony: At its root "irony" has the notion of dissembling. The word is related to an ancient Greek character in comedy called the eiron, who pretends to know less than he knows. He speaks in understatement to dissemble the boastful claims of a braggart called the alazon. Peter Childs and Roger Fowler define irony as "a mode of discourse for conveying meanings different from, and usually opposite to, the professed or ostensible ones" (Childs and Fowler 2006, p. 123). Irony's effectiveness relies on the exploitation of the distance between words and events and their contexts. D. C. Muecke identifies three basic features of irony:

(1) Irony depends on a double-layered or two-story phenomenon for success. "At the lower level is the situation as it appears to the victim of irony (where there is a victim) or as it is deceptively presented by the ironist" (Muecke 1969, p. 19). The upper level is the situation as it appears to the reader or ironist.

(2) The ironist exploits a contradiction, incongruity, or incompatibility between the two levels.

(3) Irony plays upon the innocence of a character or victim. "Either a victim is confidently unaware of the very possibility of there being an upper level or point of view that invalidates his own, or an ironist pretends not to be aware of it" (Muecke 1969, p. 20).

All irony falls into two main categories: verbal irony, which applies to a statement, and situational irony, which applies to an event (Childs and Fowler 2006, p. 123). In verbal irony a contradiction occurs between what is expressed and what is implied. The writer or speaker makes explicit one attitude or evaluation but implies a different attitude or evaluation that is often the opposite of what is expressed (Abrams and Harpham 2015, p. 186). Appreciation of verbal irony depends upon recognizing a shared disparity between what a writer says and what a writer means. Take for example, the famous dictum that opens the novel Pride and Prejudice. "It is a truth universally acknowledged, that a single man in possession of a good fortune, must be in want of a wife" (Austin [1813] 2001, p. 3). Jane Austin employs verbal irony to deride the nineteenth-century assumption that a single woman must be in search of a wealthy husband. In general, irony relies on understatement, paradox, puns, 
and other forms of wit to heighten incongruities (Childs and Fowler 2006, p. 124). In the crucifixion scene in Mark 15:29-32a, verbal irony is enhanced by clues such as "Aha" and "shaking their heads".

Those who passed by derided him, shaking their heads and saying, "Aha! You who would destroy the temple and build it in three days, save yourself, and come down from the cross!" In the same way the chief priests, along with the scribes, were also mocking him among themselves and saying, "He saved others; he cannot save himself. Let the Messiah, the King of Israel come down from the cross now, so that we may see and believe."

The irony works on two levels. On one level the speakers do not mean what they say. When the chief priests and scribes refer to Jesus as "Messiah, the King of Israel," they say this with tongue in cheek, for it is inconceivable that the long-awaited Messiah would be rejected and killed. The religious leaders believe they are upstairs in Muecke's diagram, and from their superior vantage point they view Jesus as a fraud. But in an ironic twist the verbal irony becomes situational irony. The chief priests and scribes are now downstairs, unaware of a second level to their own words. When they taunt, "Save yourself, and come down from the cross," little do they realize that Jesus's mission is to suffer and die (Mark 8:31; 9:31; 10:33-34). Similarly, the ironists are unaware of a second level of irony in their jeer, "he saved others, he cannot save himself" (Mark 15:31). As verbal irony, their jeer mocks the absurdity of a crucified Messiah; as situational or dramatic irony it voices "one of the supreme ironies of history" which eludes the religious leaders (Taylor 1960, p. 592).

Situational irony depends for its success on an incongruity or contradiction between what a speaker says and what the author intends. Whereas in verbal irony a contradiction or incongruity—shared by both speaker and reader-exists between what is said and what is intended, in situational irony the speaker is naïve about the irony and unaware that he or she is being ironical. Only the author and reader share insight into the irony. In Muecke's two-story phenomenon, the author and reader are in a superior position upstairs while the victim of the irony, the character or speaker, is downstairs unaware of the second level. Dramatic irony is a form of situational irony in which the audience or reader shares knowledge with the author about present or future circumstances of which the character is ignorant.

A famed case of dramatic irony occurs in Caiaphas's remarks to the chief priests and Pharisees: "You know nothing at all! You do not understand that it is better for you to have one man die for the people than to have the whole nation destroyed" (John 11:49-50). Although Caiaphas intends no irony, his statement drips with it. In Muecke's diagram, he is downstairs unaware of a second level of meaning to his words which the narrator exploits. The high priest's solution is merely a practical response to a troublemaker: Jesus's preaching and healing pose a threat to the safety of Israel. It is better to sacrifice one person to spare the nation than to have the Romans come and destroy the temple and the nation. Caiaphas says more than he intends but not less than what the narrator intends. A second level of meaning of which Caiaphas is unaware turns his straightforward statement into dramatic irony. The preposition "for" or "in place of" (hyper) can also have the meaning "on behalf of". Caiaphas intends "in place of". Jesus must die in place of Israel to spare the people. But the narrator intends "on behalf of". Jesus must die on behalf of the people. Jesus's death spares the people but not in the way Caiaphas thinks. The narrator clarifies the upstairs meaning for the reader: "He did not say this on his own, but being high priest that year he prophesied that Jesus was about to die for [hyper] the nation, and not for the nation only, but to gather into one the dispersed children of God" (John 11:51-52). The high priest "could not suspect that Jesus would die, not in place of Israel but on behalf of the true Israel" (Brown 1966, 1:442).

The above illustrations show the value of irony: It heightens narrative claims and truths in ways that straightforward discourse cannot achieve. There is no finer example of this function of irony than the Roman soldier's salute in the gospels: "Hail, King of the Jews" (Matt. 27:29; Mark 15:18; John 19:3). With verbal irony they mock Jesus as a dismal failure and a pretend king, while dramatic irony accents the truth. The narrator and reader who are upstairs know that the acclamation rings true in ways that the soldiers could not possibly understand. Not only is Jesus the King of the Jews, the soldiers' 
statement and actions also confirm the paradox of his rule. He is a suffering and rejected Messiah. Standard (non-ironical) discourse could not convey the nature of Jesus's mission as effectively as the gallows humor voiced by the Roman soldiers. (On irony in the New Testament see Camery-Hoggatt 1992; Duke 1985; Smith 1996, chp. 6; Resseguie 2001, pp. 28-41; Resseguie 2005, pp. 67-75.)

kernels and satellites: Seymour Chatman adopted the terms from Roland Barthes (1974) to describe the logical and hierarchical connections in a plot (Chatman 1978, pp. 53-56). Kernels are major events that move the plot forward and are essential to the plot's advancement. They "are narrative moments that give rise to cruxes in the direction taken by events" (Chatman 1978, p. 53). Since kernels determine the direction of the plot, they "cannot be deleted without destroying the narrative logic" (Chatman 1978, p. 53). On the other hand, satellites are minor events that are not crucial to the logic of the plot and can be deleted without damaging the narrative. If the kernels are viewed as the skeleton of the plot, then satellites are the flesh on the bones. They fill in, elaborate, and complete the kernel but could be deleted without affecting the plot's logic.

Frank J. Matera applied the concepts of kernels and satellites to Matthew (Matera 1987, pp. 233-53). For example, the Sermon on the Mount in Matthew 5-7 is a satellite in Matera's analysis that could be eliminated without destroying the logic of the narrative. On the other hand, the inauguration of Jesus's ministry in Matt. 4:12-17 is a kernel that is essential for the movement of the plot. The difficulty with this method of analysis is identifying the kernels that are essential to plot development from the satellites that are not. Because there is no agreed upon method to distinguish the kernels from the satellites, the concept has not gained currency in New Testament narrative criticism (Kingsbury 1991, p. Xv).

\section{kinetic character $\rightarrow$ character.}

MacGuffin $\rightarrow$ setting.

masterplot: Masterplots are "recurrent skeletal stories, belonging to cultures and individuals that play a powerful role in questions of identity, values, and the understanding of life" (Abbott 2008, p. 236). They explore the quest for life's meaning or build upon questions of origins: the quest for identity (Who are we?); the quest for meaning (Where are we going?); the quest for reconciliation (How do we find our way back home?); the quest to determine our destiny (Are we free agents or is our destiny determined?). For example, the masterplot of Sophocles' Oedipus narrative is a story of conflict between free will and a destiny determined by life's constraints. Oedipus seeks to find a future that is free from the constraints placed upon him by his own heritage and environment. Can he escape his fate and determine his direction in life? Or is his life determined by events and circumstances beyond his control? Oedipus learned from the Oracle at Delphi that he is fated to kill his father Laius, the king of Thebes, and marry his mother, Jocasta. He determines to avoid this destiny by never returning to Corinth, which he mistakenly believes to be his place of origin. On the road he meets an unknown man whom he kills, and then he marries his widow, which assures that fate triumphs over individual will. The man he killed was his father, Laius, and the widow he married was his mother, Jocasta (cf. Abbott 2008, pp. 195-97; Resseguie 2005, pp. 203-4).

The masterplot of the book of Revelation is a quest story of the people of God in search of the new promised land. As the Israelites of old faced obstacles and received divine protection on their exodus to the promised land, so the people of God in Revelation-the followers of the Lamb-replicate the masterplot of peril and divine solace on their journey to the new Jerusalem. The good characters of Revelation aid the people of God in their quest for a vanished Eden, while the evil characters hinder their quest. The pharaoh of Revelation is the dragon with seven heads and ten horns who pursues the woman clothed with the sun and attempts to destroy her with a flood from his mouth (Rev. $12: 3,13,15)$. But she is given two wings of a great eagle to escape to the wilderness where the earth comes to her aid by swallowing the pharaoh's torrent $(12: 14,16)$. All this is reminiscent of the Exodus masterplot: Pharaoh pursues the escaping Israelites to the Red Sea (Exodus 14-15); eagles' wings carry a persecuted people to safety in the wilderness (Exodus 19:4; cf. Deuteronomy 32:11-12); and the earth 
engulfs Pharaoh's army (Exodus 15:12)—just as the earth swallows the dragon's flood in Revelation. (Resseguie forthcoming (b) "Narrative Features")

Another New Testament masterplot is humankind's desire to be independent and free; yet the quest for independence can also lead to disaster and a longing to return home. In the parable of the prodigal son in Luke 15:11-24, the younger son sets out on his quest for freedom, but disaster upends his drive for independence, and he sets out on a new quest to return to the father's house.

metaphor $\rightarrow$ simile and metaphor.

mise en scène $\rightarrow$ setting.

misunderstanding $\rightarrow$ double entendre and misunderstanding.

mythos $\rightarrow$ plot.

names $\rightarrow$ characterization.

narratee: "Narratee", coined by Gerald Prince (1971), designates a fictive audience-the person or persons to whom the narrator addresses the narrative. The narratee does not exist outside the text and is reconstructed from the text proper. (See the communication box of Seymour Chatman under reader). For example, the narrator of Matthew creates a fictive, idealized audience-the narratee-to whom the narrative is addressed. This narratee is familiar with Jewish customs, the scriptures, and the norms and conventions of the first-century Jewish world. Most New Testament narrative critics do not distinguish the narratee from the implied reader, although Malbon separates the two (Malbon 2008, p. 33). On the role of the narratee see Wolf Schmid (2013).

narrative perspective $\rightarrow$ point of view/narrative perspective.

narrative criticism $\rightarrow$ introduction and narratology.

narratology: In 1969, the term "narratology" (narratologie in French) was coined by Tzvetan Todorov (1969). It is concerned with the theory and practice of narrative in all literary forms. In America, early New Testament narratology is called narrative criticism (see introduction above). In practice, New Testament narrative criticism is more concerned with the sustained interpretation of individual narratives using theory than with theory itself. On the other hand, contemporary narratology is more concerned with the development of theory than with the sustained interpretation of individual narratives (Moore 2016, pp. 33-34).

The Living Handbook of Narratology defines narratology as "a humanities discipline dedicated to the study of the logic, principles, and practices of narrative representation" (Meister 2014). The list of areas of engagement is extensive: "cognitive narratology", "critical narratology", "feminist narratology", "gender narratology", "natural narratology", "postcolonial narratology", "narrative ethics", and "rhetorical narratology" to name a few.

Cognitive narratology has only been around a little more than twenty years (Herman 2013). It focuses on the nexus of narrative and mind, including how storytellers cue the mental lives of characters and how interpreters appropriate and fill in the cues (Herman 2013). Recently, New Testament narrative critics have used cognitive narratology to broaden and deepen the description of characters in the gospels. For example, Joel Green develops the characterization of Zacchaeus in Luke 19:1-10 using cognitive narratology to show how narrative descriptors influence readers' perceptions (Green 2016). Not only does Luke rely on several character traits to describe Zacchaeus-ruler, short, rich, sinner, son of Abraham, lost; he uses spatial descriptors to thicken and enlarge the tax collector's characterization, such as up and down, in and out, and near and far. As a result, spatial notations combine with negative character traits to influence the reader's perception of the tax collector. His diminutive stature parallels his lowly status; his shortness is emblematic of his social status as an outsider even among his own townspeople. Cognitive narratology is a promising field for narrative-critical research. On New Testament narratology in Germany, see Finnern $(2010,2014)$.

narrator: The "narrator" is the one who tells the story to a fictive, idealized audience-the narratee. In a third-person narrative, the narrator refers to characters by name or by "he", "she", or "they". 
Third-person narrators know everything that needs to be known and have privileged access to characters' thoughts, motivations, and feelings. This narrator is called omniscient. All gospel narrators are third-person omniscient and intrusive narrators: narrators that not only know everything that needs to be known and have privileged access to characters' thoughts, feelings, and motivations, but also comment on characters and events and make judgments concerning them. An omniscient, intrusive narrator moves freely from character to character, event to event, and may provide inside views or asides. For example, the third-person omniscient and intrusive narrator of Mark offers this inside view (and judgment) on Jesus's disciple: "And they [the disciples] were utterly astounded, for they did not understand about the loaves, but their hearts were hardened" (Mark 6:51b-52). A narrator may also be omniscient yet remain un-intrusive. He or she describes and reports but avoids commentary or judgments. New Testament narrators are reliable narrators-that is, their perspectives and judgments coincide with those of the implied author. An unreliable or fallible narrator is one whose perspectives and judgments are at odds with the implied author and is not found in the New Testament.

In first-person narratives, the narrator speaks as "I" or "we" and is to some degree a participant in the story. The narrator may tell his or her own story ("I" as protagonist) or someone else's story ("I" as witness, Martin 1986, p. 135). The first-person narrator infers knowledge about characters' motivations and thoughts from what they do and say, but unlike the third-person omniscient narrator, he or she cannot delve into the thoughts and motivations of others. For example, the narrator of the book of Revelation is a participant in the story and uses the first person to tell the reader what he sees in heaven: "After this I looked, and there in heaven a door stood open," and "I saw a mighty angel" (Rev. 4:1; 5:2). This stance lends authority to what the narrator says and does, although it limits his ability to comment on characters. The narrator of the Acts of the Apostles is a third-person narrator-but not always. In four sections, he adopts the first-person plural—-the "we section" — to tell his story (Acts 16:10-17; 20:5-15; 21:1-18; 27:1-28:16). For example, "when [Paul] had seen the vision, we immediately tried to cross over to Macedonia, being convinced that God had called us to proclaim the good news to them" (Acts 16:10). The first person lends an air of importance to the storytelling, for now he is a participant and witness to the events and happenings. The Prologues of Luke and John also rely on first-person narration to underscore their stance as witnesses. For example, "And the Word became flesh and lived among $u s$, and we have seen his glory" (John 1:14).

Generally, New Testament narrative critics do not identify the narrator as a separate party from the implied author-just as they do not separate the narratee from the implied reader (Culpepper 1983, pp. 16-17, 43; cf. Malbon 2008, p. 33; Malbon 2011, p. 67.). (Recently, Malbon, argues that the implied author is an identifiable party from the narrator, and the narratee is separate from the implied reader (Malbon 2008, p. 33; Malbon 2011, p. 68).)

New Criticism: "New Criticism" is a form of American (and English) literary criticism that came into vogue from the early part of the twentieth century to the late 1960s. New Critics rejected the concept that the focus of literary criticism is with the biographies of authors, or the social context of a work, or the authorial intention behind a work, or the effects of literature on the reader. New Critics popularized the term affective fallacy - that is, the fallacy that a poem (or literary work) can be evaluated by its effects upon the reader. They also rejected the view that author's intended aims and means in writing a literary work are relevant for interpretation, which they called the intentional fallacy (see Wimsatt and Beardsley 1954, pp. 3-40). Rather, New Critics contend that the proper concern of literary criticism is with the detailed analysis of a work as an independent entity or a self-sufficient object.

New Criticism is known for the practice of close reading, which focuses on detailed analysis of the verbal and figurative components within a work (Abrams and Harpham 2015, p. 243). New Critics pay close attention to the words on a page and analyze small units of a text and the ambiguities of words, images, and metaphors. Of the three main components of a work- 
Author $\rightarrow$ Text $\rightarrow$ Reader

- New Critics focused exclusively on the text without regard for the author or the reader of a work. Close readings of biblical text bring out the subtlety and nuances of a narrative. In 1967, Dan Otto Via Jr. drew explicitly upon New Critical theory to show that the parables of Jesus are autonomous works in which form and content are inseparable (Via 1967). A few years later, the French literary critic, Jean Starobinski, provided an insightful close reading in New Literary History (Starobinski 1973) of the struggle with Legion (Mark 5:1-20). Robert Tannehill explored the metaphoric power, tensions, patterns, parallelisms, and paradoxes in the sayings of Jesus in his book, The Sword of His Mouth (Tannehill 1975). Phyllis Trible's reading of the book of Ruth is a classic close reading from a feminist perspective (Trible 1978). In 1979, Fishbane (1979) gave several close readings of narrative texts, prayers, and speeches in the Hebrew Bible. In The Art of Biblical Narrative (1981), Robert Alter showed the importance of repetition in biblical narratives and its affinity with repetition in short stories, novels, and poems. He opened-up a whole area of study with his analysis of type-scenes in the Hebrew Bible—for example, betrothal type-scenes—-that drew upon type-scenes in Homer. In 1982, James L. Resseguie gave a close reading of John 9 that appeared in Literary Interpretations of Biblical Narratives (Resseguie 1982a). David Rhoads offered a close reading of the Syrophoenician woman in Mark (Rhoads [1994] 2004), and Outi Lehtipuu turned his attention to the parable of the rich man and Lazarus in Luke 16:19-31 (Lehtipuu 1999).

Today, narrative criticism rejects the extremes of New Criticism - for example, that an analysis of a literary work is separable from the response of the reader (cf. the affective fallacy). The development of reader-response criticism is partly a reaction against New Critics' rejection of the affective responses of the reader. Nevertheless, narrative criticism has benefited from the New Critical recognition of the organic unity of a text and its method of close, detailed readings of narratives. On New Criticism see Resseguie (2007).

omniscient narrator $\rightarrow$ narrator.

ostranenie ("making strange") $\rightarrow$ defamiliarization.

parallelism: "Parallelism" is the similarity in structure of a pair of words, phrases, clauses, or syntactical arrangements. For example, in Rev. 22:11:

A Let the evildoer still do evil,

$\mathrm{A}^{\prime}$ and the filthy still be filthy,

$\mathrm{B}$ and the righteous still do right,

B' and the holy still be holy.

The first two clauses (A, $\left.\mathrm{A}^{\prime}\right)$ are synonymous parallelism, as are the last two (B, $\left.\mathrm{B}^{\prime}\right)$. The parallel clauses reiterate the same concept but use different words. Notice also that the two parts are marked off by the same adverb and verb combination: "still do" / "still be" / "still do" / still be". And, finally, the last two clauses contrast with the first two. Antithesis is also a form of parallelism in which the second line or couplet contrasts with the first. John 9:39—as well as the above example—illustrates antithesis:

I came into the world for judgment

so that those who do not see (A)

may see (B),

and those who do see (B')

may become blind $\left(\mathrm{A}^{\prime}\right)$. 
peripety or peripeteia ("reversal") $\rightarrow$ plot.

plot: "Plot" is an elusive term and any definition is likely to be incomplete. Yet, an understanding of plot is important to determine the structure, unity, and direction of a narrative. Plot is the designing principle, the sequence of events or incidents that make up a narrative. Events include actions (or acts) that bring about changes of state in the characters. Or events may be the actions of characters that bring about changes of state in narrative events (Chatman 1978, pp. 44-45). A character's acts are his or her physical actions, speech, thoughts, feelings, and perceptions. "What do characters think, feel, or do, and how does this bring about a change in narrative events?" is a question of plot. By and large, a character is the subject of acts; she or he initiates acts that bring about changes in the plot. But a plot does not consist solely of acts. It also is made up of happenings. As the term suggests, happenings are things that happen to a character or are events that occur in a setting. In happenings, the character is the object—not the subject—of actions; the affected, not the effector (Chatman 1978, p. 45). When we ask, "What happens to a character and why?" we are asking a question related to plot. When we ask, "What happens in a setting such as the stilling of the storm on the sea, and how does that event change the disciples' perception of Jesus?" we are developing the notion of plot. Plot and character are thus intertwined in a narrative. Henry James famously stated the inseparability: "What is character but the determination of incident? What is incident but the illustration of character?" (James [1884] 1948, p. 13).

Aristotle defined a plot (mythos in Greek) as a continuous sequence of events or actions with a beginning, middle, and end. "A beginning is that which does not follow necessarily from something else, but after which a further event or process naturally occurs. An end, by contrast, is that which itself naturally occurs, whether necessarily or usually, after a preceding event, but need not be followed by anything else. A middle is that which both follows a preceding event, and has further consequences" (Aristotle 1995 Poetics 7, 1450 ${ }^{\mathrm{b}}$ 27-31). Paul Goodman defines plot as follows: "In the beginning anything is possible; in the middle things become probable; in the ending everything is necessary" (Goodman 1954, 14). A plot is thus a unified whole. It "should be so structured that if any [part] is displaced or removed, the sense of the whole is disturbed or dislocated" (Aristotle 1995 Poetics 8, $1451^{\mathrm{b}}$ 32-34).

A story, however, is not a plot. Although both story and plot have sequences of events that are linked, a plot goes further and links sequences by cause and effect. A story requires that we ask, "What happens next?" whereas a plot requires that we ask, "Why do things happen as they do?" E. M. Forster illustrates the difference between a story and a plot in the following example:

The king died and then the queen died.

The king died, and then the queen died of grief (Forster [1927] 2005, p. 86).

In the first instance, the events are strung together with no causal connection between the two. The queen could have died from an accident-falling down the stairs, for instance-or from health problems such as heart disease. But there is nothing in the brief story to suggest that the queen's death is directly related to the king's death. The only link between the two is the suggestive but inconclusive "and then". In the second instance, the same story is told with two additional words that suggest a relationship between the events. It turns the story into a plot by answering the question "why did the queen die?" Biblical plots rely on cause and effect to answer some of life's most important questions. "Where did we come from?" "Where are we going?" "What is our purpose?"

Almost all plots involve a clash of actions, ideas, points of views, desires, or values. The conflict may be physical, mental, emotional, spiritual, or moral. Plots frequently involve contests between protagonist and antagonist, or groups of good and bad characters. Conflicts may be external or internal. External conflicts include clashes with other characters, whether villains (an evil character, such as Satan) or adversaries (e.g., religious leaders) whose values, goals, or norms conflict with the protagonists. The religious authorities are often pitted against Jesus (for example, Matt. 9:14-17; Mark 
2:18-22; Luke 5:33-39). Other clashes in the gospels involve battles with nature. The quelling of the tempest on the Sea of Galilee is an example of a battle with nature (Matt. 8:23-27; Mark 4:35-41; Luke 8:22-25). Still other conflicts involve battles with the supernatural such as the healing of a man possessed by demons (Matt. 8:28-34; Mark 5:1-20; Luke 8:26-39). Some clashes between Jesus and others involve conflicts with the norms and values of the dominant culture of the first century (Mark $7: 1-23)$.

Other plot conflicts are internal-for example, decisions that a protagonist or others must make. The protagonist, Jesus, is faced with an internal conflict in the garden: he desires to have the cup of suffering taken away from him, but he also wants to follow the Father's will (Matt. 26:36-46; Mark 14:32-42; Luke 22:39-46). A character may also face a dilemma that involves two choices or actions, both of which appear undesirable. The decision may determine success with a favorable ending or failure with a tragic result. For example, the Rich Young Man faces a conflict of decision concerning his wealth (Matt. 19:16-22; Mark 10:17-22; Luke 18:18-23). Then there are conflicts within a character concerning his goals and values. The rich farmer in Luke 12:13-21 sets a goal of building larger barns, but unseen events-his impending death-determine the outcome.

Northrop Frye identifies two common plot patterns in the New Testament (Frye 1981, pp. 169-71). One pattern is a U-shaped plot which is the shape of a comedy. This pattern begins at the top of the $\mathrm{U}$ with a state of equilibrium, a period of prosperity or happiness that is disrupted by disequilibrium or disaster. Adversity, misunderstanding, or rebellion propels the plot downward to disaster or bondage. At the bottom of the $\mathrm{U}$, the direction is reversed by a fortunate twist, divine deliverance, an awakening of a character to her or his tragic circumstances, or some other action or event that results in an upward turn. Aristotle referred to the reverse in fortunes as a peripety or peripeteia (Greek for "reversal," Aristotle 1995 Poetics 11. (A peripety can move the plot upward to success as in a comedy or downward to failure or destruction as in a tragedy). The reversal depends frequently on a recognition or discovery, which Aristotle called an anagnorisis-a change in the protagonist from "ignorance to knowledge" involving "matters which bear on prosperity or adversity" (Aristotle 1995 Poetics 11). The protagonist recognizes something of great importance that was previously hidden or unrecognized. The upward change in the U-shaped plot marks the beginning of the dénouement or resolution of the plot. An action is taken that ends in success, or the misunderstanding is solved, or rebellion ceases. The upward turn of the $U$ represents movement toward a new state of equilibrium - a return home, reconciliation, new life. The top of the $U$ is characterized by happiness or prosperity or, in biblical terms, peace, salvation, and wholeness.

An example of a U-shaped plot is the parable of the prodigal son in Luke 15:11-24. The beginning of the downward turn occurs when the younger son asks his father for his share of the property and sets out to a "distant country" (Luke 15:13). The physical setting—“a distant country"—-suggests a story of alienation or rebellion, or at the very least a desire for freedom and independence. However, disaster strikes. He faces personal adversity when he squanders the property given to him by his father (Luke 15:13-14a), and then his disaster is compounded by a famine in the land (Luke 15:14b). The nadir is summarized with an economy of words: "no one gave him anything" (Luke 15:16). This is the bottom of the U-shaped plot. The peripety occurs with a recognition scene: "he came to himself" (Luke 15:17a) and "he set off and went to his father" (Luke 15:20a). The upward turn of the U-shaped plot and the dénouement occur when the father goes out to meet the son while he is "still far off" (Luke 15:20b). The clothing (best robe, sandals, ring) and grand feast represent the top of the $U$, a new state of equilibrium. Other U-shaped plots in the New Testament include the four gospels and the book of Revelation (Resseguie 2005, pp. 206, 213-40).

Frye's second pattern is an inverted U-shaped plot, which is the shape of a tragedy. The introduction of a conflict initiates the rising action or the beginning of the upward turn of the inverted $\mathrm{U}$. The conflict is developed and complicated until the rising action reaches the climax of the protagonist's fortunes. This is the top. A crisis or turning point marks the reversal of the protagonist's fortunes and the beginning of the dénouement (also called catastrophe in tragedies). Sometimes there is a 
recognition scene where the protagonist discovers something of great importance that was previously unseen. The final state is disaster, adversity, and unhappiness. Frye's inverted U-shaped plot is like Freytag's Pyramid (Freytag 1896), which envisions a tragedy as an inverted V or pyramid. The tragedy begins with an exposition of characters, the setting, and other facts necessary to understand the plot. It is followed by a conflict and the rising action that develops and elaborates the conflict. The top of the inverted $\mathrm{V}$ or pyramid is the climax and the reversal of action from rising to falling. The dénouement ends in disaster.

Why analyze narratives as comedies (U-shaped plots) or tragedies (inverted U-shaped plots)? An analysis of the parable of the ten bridesmaids in Matt. 25:1-13 will illustrate. The parable is a tragedy for the five foolish bridesmaids. The exposition introduces the setting-a marriage feast-and the characters-five wise maidens who bring extra flasks of oil and five foolish bridesmaids who bring no additional oil. The conflict occurs when "the bridegroom was delayed" (Matt. 25:5a). A crisis-the sudden arrival of the bridegroom at midnight - then marks the turning point in the fortunes of the five foolish attendants. Since the foolish have brought insufficient oil for their lamps, the falling action is a series of frantic attempts to reverse the downward turn to disaster. They ask the wise to share their oil, but they decline. And then they rush to the market to buy more oil. But this only complicates their dilemma, for they are late for the party and the door is locked. Their recognition scene comes too late to make a correction in their tragic flaw (hamartia in Greek, meaning "error" or "mistake of judgment"). Although they plead with the bridegroom to open the door, they are met with the same sort of indifference that they demonstrated in their lack of preparation for the wedding: "Truly, I tell you, I do not know you" (Matt. 25:12).

This illustrates the importance of plot analysis. Tragedies and comedies develop and elaborate anagnorisis (recognition), peripety (reversal), and hamartia or fatal flaw. Recognition scenes illuminate something of great importance that was hitherto unknown to the protagonist or to a character. The recognition scene for the Prodigal Son is the realization that his present state of servitude in a far land does not compare with the pleasant condition of his father's hired hands; therefore, he sets about to reverse the downward turn of the $\mathrm{U}$. The recognition scene of the five foolish bridesmaids comes too late to reverse their fate. However this does not preclude the reader from benefitting from their decisions. The reader can ask "What was their hamartia or fatal flaw that sealed their fate?". Often hamartia is rooted in hubris-"pride" or "overwhelming self-confidence"- that leads a character to assume that he or she is in full control of a situation. The five bridesmaid's assumption is a classic illustration of hubris or foolishness. Peripety is the turning point in a plot when the arc of the $U$ either moves upward (as in comedy) or downward (as in tragedy). The reader benefits from the choices the protagonist or group of characters make when faced with a crisis. On plot, see also fabula and syuzhet and masterplot in this glossary. On recognition scenes in John, see Larsen (2008).

point of view/narrative perspective: Point of view "signifies the way a story gets told" and elaborates the relationship between the storyteller and the story (Abrams and Harpham 2015, p. 300). Some narrative critics prefer the concept of focalization. Point of view focuses on the way the author presents the reader with the constitutive features of a narrative: characters, dialogue, actions, setting, and events. Narrative perspective is a complex and controversial concept, and the literary critic Susan Sniader Lanser suggests why: "Unlike such textual elements as character, plot, or imagery, point of view is essentially a relationship rather than a concrete entity. As it tends to evade stabilization into the language of 'things', it has been difficult to grasp and codify" (Lanser 1981, p. 13, emphasis Lanser).

The Russian literary critic, Boris Uspensky, identifies five planes on which point of view is expressed in a work: (1) spatial, (2) temporal, (3) psychological, (4) phraseological, and (5) ideological (Uspensky 1973). Each plane represents an observable position that the implied author or narrator takes in relationship to the textual world. The spatial plane describes the stance in space that the narrator takes in relation to the text. For example, the narrator may offer a "bird's-eye" perspective on characters and events that results in distancing the reader from individual characters and actions. Alternately, the narrator may adopt the spatial stance of a character and move with that character throughout 
the narration, observing what the character says and does (Uspensky 1973, pp. 58-59). Further, the narrator may adopt the point of view of an observer within a scene, avoiding the perspective of any one character. In this instance, the point of view is that of the narrator and not of the character. For example, the narrator may describe the guests at a banquet scene and move from one character to another as if she or he were also a guest at the table. Finally, the narrator may simply be an invisible, roving presence as in a moving camera and montage—present but invisible (Resseguie 2016, p. 83).

An example of Uspensky's spatial point of view can be seen in the spatial (and temporal) stance of the third person, omniscient and intrusive narrator in John 2:13-22. After Jesus says, "destroy this temple, and in three days I will raise it up" (John 2:19), the hearers naturally assume he is talking about the temple complex that had been under construction for forty-six years. The narrator intervenes to clarify the misunderstanding: "But he [Jesus] was speaking of the temple of his body" (John 2:21). Then he continues: "After he was raised from the dead, his disciples remembered that he had said this; and they believed the scripture and the word that Jesus had spoken" (John 2:22). In this instance, the spatial position of the narrator is as an omniscient and intrusive presence that corrects the misperception of the hearers. Additionally, the narrator adopts posterior narration to clarify Jesus's saying — that is, a post-resurrection perspective on events and happenings.

Temporal point of view refers to (1) the pace of narration and (2) the temporal distance between the moment of telling and the actual events (Lanser 1981, p. 198). The temporal distance of the narrator in the Fourth Gospel is a post-resurrection point of view or posterior narration, which is illustrated in the example above (John 2:20-2). Temporal pace focuses on the acceleration of narrative storytelling or the slowing down of narrative pace. With narrative retardation (slowing down the pace of narration), events and happenings are foregrounded, which forces the reader to notice what is important. For example, the narrative pace in John moves from rapid narration in the first two and half years of Jesus's ministry (chapters 1-12) to a snail's pace in the last half, which depicts Jesus's last twenty-four hours (chapters 13-19). The retarded pace magnifies the passion so that as Jesus is "lifted up" in his ordeal leading to the cross (cf. John $3: 14 ; 8: 28 ; 12: 32$ ), the narrator "lifts up" the events with narration that elongates and amplifies their significance (Resseguie 2001, p. 187).

Psychological point of view focuses on behaviors. Uspensky and Lanser describe two ways human behavior may be observed by the narrator (Uspensky 1973, p. 83; Lanser 1981, p. 207). If the narrator takes the point of view of an outside observer, then the storyteller is restricted to what can be observed objectively. This stance corresponds to a camera that records the behavior of a person without access to internal consciousness. On the other hand, the narrator may set aside the perspective of an objective observer and record the feelings, thoughts, and motivations of a character. A third possibility is that the psychological point of view may be described from the perspective of a character. For example, an interior monologue reveals the unspoken thoughts and lays bare a character's perspective for the reader to evaluate. This aspect of point of view also allows the implied reader to identify conflicts and opposing points of view. A character's point of view that goes against the norms, beliefs, and worldview of the narrator creates distance between the character and the reader, while a character's perspective that agrees with the narrator's stance creates affinity.

Phraseological point of view focuses on the narrator's discourse and characters' speech. If the narrator speaks in his or her own voice, she or he expresses a point of view-however subtle. The narrator may use the idiosyncrasy of a character's speech to express the narrative's point of view. Alternately, the narrator's speech can seamlessly merge with a character's speech, or vice versa. In this instance, the narrator has taken the character's point of view as his own, or the narrator has imbued the character's speech with his own point of view. For example, John 3:13-21 is "a classic instance of the blending of the narrator with Jesus' voice" (Culpepper 1983, p. 42). Does the narrator speak in his own voice or is this Jesus's voice? The narrator's phraseological point of view also shapes the reader's response to a character. For example, Judas's actions are judged harshly in John 12:6: "He said this not because he cared about the poor but because he was a thief; he kept he common purse and used to 
steal what was put into it." The narrator's point of view has sealed the reader's judgment concerning Judas's nefarious reputation.

Ideological point of view is not only "the most basic aspect of point of view" but also the "least accessible to formalization, for its analysis relies, to a degree, on intuitive understanding" (Uspensky 1973, p. 8). It focuses on the norms, values, beliefs, and general worldview of the implied author, narrator, or characters. An ideological perspective may be stated outright-what Susan Lanser calls "explicit ideology" —or it may be embedded at "deep-structural" levels of the text (Lanser 1981, pp. 216-17). The ideological point of view of the Fourth Gospel is an example of explicit ideology. "The Word became flesh [sarx] and lived among us, and we have seen his glory [doxa], the glory as of a father's only son, full of grace and truth" (John 1:14). With astuteness beyond the ordinary, Rudolf Bultmann summarizes John's ideology: “The $\delta \delta \xi \alpha$ is not to be seen alongside the $\sigma \alpha \alpha \varrho$, nor through the $\sigma \alpha \alpha^{\prime} \xi$ as through a window; it is to be seen in the $\sigma \alpha \dot{\alpha} \xi$ and nowhere else. If man wishes to see the $\delta$ ó $\xi \alpha$, then it is on the $\sigma \alpha \dot{\alpha} \xi$ that he must concentrate his attention without allowing himself to fall victim to appearances" (Bultmann 1971, p. 63, emphasis Bultmann). Some characters in the Fourth Gospel—the crowds and the religious leaders, for example—miss the glory and see Jesus's flesh alone. They stumble over his words, misconstrue his actions as misguided, and conclude that he is lawless. Others-the Samaritan woman, the man born blind, Mary of Magdala, the beloved disciple, and Thomas, for example — see the glory in the flesh, the otherworldly in the ordinary. If a character/reader falls victim to appearances and misconstrues Jesus's actions as antagonistic, then he or she becomes blinded to the doxa in the sarx. On the other hand, if a character/reader glimpses the glory in the flesh, the supranatural in the natural or the ordinary, then she or he comes to believe that "Jesus is the Messiah, the Son of God" (John 20:31; Resseguie 2013a, pp. 93-95; see also Sheridan 2016, p. 215). On point of view see Burkhard Niederhoff (2013b), Gary Yamasaki (2007), and Resseguie (Resseguie 1982b, 2001, 2005, pp. 167-96).

posterior narration $\rightarrow$ point of view/narrative perspective.

primacy and recency effect: The material that occurs first in a plot and affects the reader initially is known as the" primacy effect," while what follows is called the "recency effect". The order of events in a plot creates expectations in the reader (the primacy effect) that are fulfilled, modified, or even shattered by what comes later in the narrative (the recency effect; Perry 1979, pp. 35-64, 311-61). Three types of primacy/recency effects have practical and theoretical implications for the reading of New Testament literature (Sternberg 1978, pp. 90-158).

(1) A primacy effect can be developed, elongated, and reinforced by the recency effect.

(2) A recency effect can undermine, shatter, or in some other way subvert the primacy effect.

(3) A recency effect can modify, exploit, or revise the primacy effect.

An example from the book of Revelation illustrates a primacy effect that is reinforced in a counterintuitive way by what comes afterwards. In Rev. 5, John hears the voice of an elder announce the appearance of an animal of conquest that is worthy to open a mysterious scroll: "See, the Lion of the tribe of Judah, the Root of David, has conquered, so that he can open the scroll and its seven seals" (Rev. 5:5). Although this is what John hears, it is not what he sees. "Then I saw between the throne and the four living creatures and among the elders a Lamb standing as if it had been slaughtered, having seven horns and seven eyes, which are the seven spirits of God sent out into all the earth" (Rev. 5:6). Is the primacy (what John hears in Rev. 5:5) reinforced by the recency effect (what John sees in Rev. 5:6)? Is it undermined by the recency or is the primacy effect revised and modified by the recency effect? In this instance, the primacy effect is not overturned by what follows, although it is fulfilled in a surprising way. Jesus is indeed the Lion of Judah who is the descendent of the root of David (Koester 2014, pp. 375-76, 385). Yet the primacy/recency effects force the reader to reconcile the expectation of a lion's appearance on the one hand with the appearance of a slaughtered yet risen lamb on the other. The recency effect adds a counterintuitive message to the primacy. The conquering might of 
God's Messiah is found in a slaughtered lamb that is risen (Boesak 1987, pp. 56-57; Resseguie 2009, pp. 118-19).

A second example establishes a primacy effect that is clarified and elongated by what comes later. In Rev. 7:4, John hears the number of those who were sealed: one hundred and forty-four thousand, twelve thousand from each of the twelve tribes of Israel. The one hundred and forty-four thousand is a symbolic number of completeness, representing all of God's Israel. But what John sees is different from what he hears: "After this I looked, and there was a great multitude that no one could count from every nation, from all tribes and peoples and languages, standing before the throne and before the Lamb, robed in white, with palm branches in their hands" (Rev. 7:9). The recency effect reinterprets and expands what John hears in Rev. 7:4-8. God's Israel is the symbolic one hundred and forty-four thousand from the twelve tribes of Israel (primacy effect); but that number is not limited to the twelve tribes of Israel. It includes a countless throng from every nation and tribe and people and language on earth (recency effect; Resseguie 2009, p. 138).

A third example illustrates a primacy effect that is overturned by the recency. In Revelation 13:11, John sees a beast arise from the earth that has "two horns like a lamb" (13:11a). But the expectation of a lamblike creature is immediately thwarted when the beast opens its mouth and speaks "like a dragon" (13:11b). Although the primacy effect raises the expectation of an unthreatening animal like a lamb, the recency effect proves the lie of this assumption. The beast is a fraud, a poseur, a wolf in sheep's clothing (cf. Matt. 7:15), for when it speaks, its discourse reveals its identity. It is the progeny of the "great dragon" (cf. Rev. 12:9). (See also Mark 10:29-30 under defamiliarization above. The primacy effect is overturned by the addition of "with persecutions" - the recency effect.)

protagonist $\rightarrow$ character.

reader: Who is the reader of a narrative? Who is the author? And what is the role of the flesh and blood reader? All narratives have parties within and outside the text. The following communication diagram by Seymour Chatman identifies the author outside the text from the author within. Chatman also recognizes that there is a reader outside the text-a real, flesh and blood reader-that is not the same as the reader within the text (Chatman 1978, p. 151).

$$
\begin{gathered}
\text { Narrative Text } \\
\text { Real author } \rightarrow \text { Implied author } \rightarrow(\text { Narrator }) \rightarrow(\text { Narratee }) \rightarrow \text { Implied reader } \rightarrow \text { Real reader }
\end{gathered}
$$

The above diagram shows the parties external and intrinsic to a narrative. The real author and the real reader are extrinsic and accidental to narratives. On the other hand, the implied author, narrator, narratee, and implied reader are immanent to narratives. In Chatman's view the narrator and narratee are optional parties and thus the parentheses above. All parties within the narrative are reconstructed from the text itself and do not exist as entities apart from the text.

The real author creates a second self or persona called the implied author (Wayne Booth's term) that is within the narrative. The implied author is not the real author but the author's second self that builds the narrative structure. The narrative critic analyzes the choices and directives of the implied author-such as his or her style, the commentary on characters, and the Weltanschauung (worldview) of the implied author. For example, the writer of the book of Revelation-John the prophet on the Island of Patmos-creates a second self, the implied author (who is also the narrator) that tells the story to the implied reader. The implied reader of Revelation is not an actual flesh and blood reader; this reader is a fictive, idealized reader of the first-century that is in the implied author's mind when he creates the narrative.

Narrative critics focus on the implied reader and the way he or she reads the narrative. Whereas flesh and blood readers allow biases, socio-cultural instincts, and accumulated experiences to influence 
their reading the story, the implied reader understands and interprets the narrative in the manner the implied author intends. The real reader who adopts the role of the implied reader knows the conventions of the implied author of the first century and assembles the message according to the author's design. This implied reader knows koine Greek, recognizes the implied author's historical and socio-cultural stance, understands references to earlier works, and accepts the implied author's worldview. The actual reader, however, may resist—even reject outright—the implied author's worldview, but as an implied reader she or he accepts the author-in-the-text's worldview.

On the role of the real reader as a "resisting reader" see Reinhartz (2001, pp. 81-98). See also the short introduction to feminist criticism by Janice Capel Anderson in Mark and Method (2008).

reader-response criticism: "Reader-response criticism" pays close attention to the actions of the reader and focuses on what the text does to the reader (Resseguie 1984, 2016). Any literary work has three main components-

Author $\rightarrow$ Text $\rightarrow$ Reader

This criticism gives the reader an essential role in the production of textual meaning. An examination of the text in and of itself is replaced by an analysis of the reading process: a sequential reading of the text with the reader's ongoing responses. The literary critic Stanley Fish describes the temporal, sequential approach in this way: "The concept is simply the rigorous and disinterested asking of the question, what does the word, phrase, sentence, paragraph, chapter, novel, play, poem do? And the execution involves an analysis of the developing responses of the reader in relation to the words as they succeed one another in time" (Fish 1980, pp. 26-27, emphasis Fish).

Some reader-response critics give more interpretative authority to actual flesh and blood readers than others. At one end of the spectrum are Gérard Genette [1972] (1980) and Prince (1973) who focus on the responses of the reader in the text. The reader is inscribed within the text and responds the way the implied author expects. The role of a flesh and blood reader is to identify the responses of the reader in the text and respond in the same way. At the other end of the spectrum is the subjective approach of Norman Holland (1975a, 1975b) and David Bleich (1975) who give the actual reader dominance over the text. Holland's and Bleich's readers are flesh and blood readers that determine the meaning of the literary work through their responses to the text. A third approach sees the reader as one who interacts with the text. This reader is neither confined within the text nor entirely free to produce textual meaning. Rather the reader is an actual reader that has limits placed on him or her in the production of textual meaning. Wolfgang Iser $(1971,1972,1974,1978)$ calls this reader an "implied reader"-one who interacts in a dialectical fashion with the text. Textual meaning is a result of this of reader-text interaction.

Several New Testament critics adopt the insights of Wolfgang Iser in their analyses of New Testament narratives (Culpepper 1983; Scott 1989; Roth 1997; Darr 1992, 1998; Fowler 1991; Fowler 2008, pp. 70-74; Howell 1990; Kurz 1993; Powell 2001; Resseguie 1984, 2016). Two of Iser's critical assumptions are generally accepted by narrative and reader-response critics (Resseguie 1984; Resseguie 2016, pp. 8-12). The first concerns the role of the reader in the production of textual meaning. The reader is active-not passive-and contributes to the text's meaning by filling in information that is implied but not written. The implied sections of a text are called "gaps," areas of "indeterminacy", or "blanks," and the assumption is that every text has gaps that the reader completes in the reading process. Iser calls the gap-filling by the reader the "realization" (Konkretisation) of the work. Thus, an important distinction is made between the "text" written by the author and the "work" realized by the reader. "The work is more than the text, for the text only takes on life when it is realized, and furthermore the realization is by no means independent of the individual disposition of the reader-though this in turn is acted upon by the different patterns of the text. The convergence of text and reader brings the literary work into existence" (Iser 1974, pp. 274-75). Although the work is the 
realization of the text by the reader, he or she is somewhat limited in the production of meaning. Iser uses the image of two people gazing at the stars to illustrate how the reader contributes to textual meaning. "Both [may] be looking at the same collection of stars, but one will see the image of a plough, and the other will make out a dipper. The 'stars' in a literary text are fixed, the lines that join them are variable" (Iser 1974, p. 282). The Iserian reader selects and organizes the parts of a text, fills in gaps, and develops an interpretation, but the written portions of the text place limits on the reader's participation in the formation of the work. Although this reader is called an "implied reader" (impliziter Leser or "implicit reader") in the English translations of Iser's works, he or she is different from Wayne Booth's and Seymour Chatman's "implied reader" (see reader above). Whereas Booth's and Chatman's reader is a property of the text and assembles the text in the way the "implied author" expects, the Iserian reader is an intermediary between the real reader and the ideal reader, filling in the gaps in his or her own way and assembling textual meaning according to the parameters set by the implied author. Although the implied reader is a function of the real reader's mind, he or she is called into being by an authorial text that asks to be read in a certain way (Iser 1978, pp. 27-38).

A second critical assumption concerns the maneuvers of a reader as she or he realizes the literary work. Iser paid close attention to the process of reading, which is one of anticipation of what lies ahead, frustration of unfulfilled expectations, retrospection, and reconceptualization of new expectations. The reader approaches the text with a "repertoire" that consists "of all the familiar territory within the text. This may be in the form of references to earlier works, or to social and historical norms, or to the whole culture from which the text has emerged" (Iser 1978, p. 69). But this familiar repertoire is made to seem strange by textual strategies that disorient the reader and forces her or him to modify expectations and to reconceptualize new information. The textual strategy of readerly disorientation is called defamiliarization (Iser 1974, p. 87), which encourages the reader to anticipate outcomes, only to have expectations frustrated and revised. Familiar elements of the reader's repertoire are backgrounded or foregrounded, diminished or highlighted, trivialized or magnified, so that a "strategic over magnification, trivialization, or even annihilation" of the familiar occurs. The reading process is a continual revision of expectations and the formation of new expectations. "We look forward, we look back, we decide, we change our decisions, we form expectations, we are shocked by their nonfulfillment, we question, we muse, we accept, we reject; this is the dynamic process of recreation" (Iser 1974, p. 288).

Iser is criticized for unproblematically distinguishing between the determinate and indeterminate parts of a text. How does the reader know that she or he has correctly identified the gaps and has filled them in to the satisfaction of the implied author? Also problematic is how the real reader avoids imposing his or her disposition and socio-cultural stance upon the final product? Nevertheless, Iser's theory of the reading process-anticipation, frustration, retrospection, and reconstruction-is a viable theory of the temporal reading process.

Recently, narrative critics have recognized the importance of the reader as an active participant in the production of textual meaning. For example, Powell (1990, p. 21; Powell 2001, p. 63) and Resseguie (2016) have merged narrative-critical approaches with reader-oriented criticism to form readings that are focused not only on the literary text itself; they also consider the essential role the reader plays in the production of the work. Powell regards narrative criticism as a "subset or variety of reader-response criticism," (Powell 2001, p. 63), and, more recently, he speaks of "reader-oriented narrative criticism" (Powell 2011, pp. 36-42). The third edition of Rhoads et al.'s Mark as Story (Rhoads et al. 2012) also moved towards a reader-oriented or audience-oriented narrative criticism with a discussion of the "ideal audience" (Rhoads et al. 2012, pp. 138-44) and an epilogue on "Reading as a Dialogue: The Ethics of Reading" (Rhoads et al. 2012, pp. 153-56).

On reading strategies see primacy and recency effect in this glossary. Important surveys of reader-response criticism are Jane P. Tompkins (1980), Suleiman and Crossman (1980), and Steven Mailloux (1982). Gerald Prince offers a critique of the Iserian reader in his article "Reader" in The Living Handbook of Narratology (Prince 2013). See also "Reader-Response Criticism" in The Postmodern 
Bible (Castelli et al. 1995, pp. 20-69) and Moore (1989) for critiques of reader-oriented approaches to biblical literature.

reliable narrator $\rightarrow$ characterization and narrator. repetition $\rightarrow$ sequence of action.

rhetoric (figurative language): "Rhetoric" is the art of persuasion. It breathes life into a narrative and influences how the reader feels and thinks about what the implied author says. Rhetoric is an integral part of every mode of expression and is the means by which the implied author convinces the implied reader of the narrative's point of view, norms, beliefs, values, and worldview. The narrative critic is interested in the rhetorical devices (figurative language) and techniques that an implied author uses to persuade the reader to make a proper interpretation of a work - that is, the informed conclusions that the implied author wants the reader to make. The rhetorical devices discussed in this glossary are (1) figures of speech and (2) figures of thought.

Figures of speech or rhetorical figures (also called schemes from the Greek word for "form") depart from customary or standard usage of language by the order and pattern of words and phrases. Although figures of speech use words or phrases in their customary or literal manner, they achieve special effects by the arrangement of words, phrases, clauses, and syntactical forms. For example, "the sabbath was made for humankind, and not humankind for the sabbath" (Mark 2:27) is a figure of speech that achieves special effects by the arrangement of words in a reverse pattern, which is called a chiasmus (sabbath/humankind//humankind/sabbath). In this glossary anaphora, antithesis, chiasmus, parallelism, rhetorical question, and sequence of action (repetition) are explained.

Figures of thought (also called tropes meaning "turns" of phrases) are words or phrases that depart from customary or standard ways of using the language. This rhetorical feature is different from figures of speech. Whereas figures of speech use language in the customary, standard, or literal way, figures of thought use words and phrases in a nonliteral way. Verbal irony is an example. When the soldiers at the crucifixion salute Jesus as "King of the Jews," (Matt. 27:29; Mark 15:18; John 19:3), they do not mean what they say. But the implied reader enjoys the irony-for what they say is precisely what the implied author intends. In this glossary, double entendre and misunderstanding, simile and metaphor, and verbal irony are discussed. [Note: rhetoric is restricted to figurative language in this glossary. However, it is an expansive and multifaceted concept. The reader should consult James Phelan (2005a, 2005b) for a discussion of rhetoric.]

\section{rhetorical figures $\rightarrow$ rhetoric.}

rhetorical question: A "rhetorical question" is a statement in the form of a question that does not expect a reply but is stated to achieve greater persuasive power than a direct statement. The answer to a rhetorical question is usually obvious and is the only one available. For example, when the Pharisees complain about the plucking of grain by Jesus's disciples on a sabbath, Jesus resorts to rhetorical questions to dismantle their complaint.

Have you not read what David did when he and his companions were hungry? He entered the house of God and ate the bread of the Presence, which it was not lawful for him or his companions to eat, but only for the priests. Or have you not read in the law that on the sabbath the priests in the temple break the sabbath and yet are guiltless? (Matt. 12:3-5)

A rhetorical question states the obvious and, in this instance, draws upon two portions of the Torah to undermine the Pharisees' objection.

round character $\rightarrow$ character.

Russian formalism $\rightarrow$ defamiliarization. 
sandwich narrative (intercalation): A "sandwich narrative" is a framing device in which one narrative is tucked inside another narrative. The embedded or intercalated narrative (B) interrupts the framing narrative $\left(\mathrm{A}, \mathrm{A}^{\prime}\right)$, which resumes after the embedded narrative ends. For example, Mark splits a narrative in half to nestle a second narrative within the framing narrative (Kermode 1979, pp. 128-34; Edwards 1989; Shepherd 1995; Resseguie 2005, pp. 54-55; Rhoads et al. 2012, pp. 51-52). The framing narrative may comment on the embedded narrative by either comparison or contrast, or the embedded narrative may comment on the framing narrative.

A famed example of a framing narrative and its embedded narrative is the cursing and withering of the fig tree and the cleansing of the temple in Mark. Whereas Matthew has the cursing and withering as a single event that happens after the cleansing of the temple (Matt. 21:18-19), Mark separates the cursing from the withering and uses it to frame the cleansing of the temple:

A Cursing of the Fig Tree (Mark 11:12-14)
B Cleansing of the Temple (Mark 11:15-19)
A $^{\prime}$ Withering of the Fig Tree (Mark 11:20-21)

The framing narrative $\left(\mathrm{A}, \mathrm{A}^{\prime}\right)$ provides a commentary on the embedded narrative (B). Other intercalations in Mark include: (1) a narrative about Jesus's family (3:20-21,31-35) frames an accusation that he is demon possessed (3:22-30); (2) a story about Jairus and his daughter (5:21-24; 35-43) frames the story of a woman with a hemorrhage (5:25-34); (3) a story about the sending and return of the Twelve (6:7-13, 30-32) frames the narrative of the death of John the Baptist (6:14-29); (4) a story of conspiracy and intrigue $(14: 1-2,10-11)$ frames a story of the anointing of Jesus at Bethany (14:3-9), and (5) the story of Peter's denial (14:53-54, 66-72) frames Jesus's trial before the Sanhedrin (14:55-65).

scheme $\rightarrow$ rhetoric (figurative language).

sequence of action (repetition): "Sequence of action" is a form of repetition that relies on actions in numerical series (of two and three, for example) to create emphasis. Rhoads, Dewey, and Michie refer to the repetition of twos in Mark as two-step progression (Rhoads et al. 2012, pp. 49-51). Although the second step appears to repeat the first, it adds new information that clarifies or amplifies the first step. For example, Mark uses two-steps to clarify the setting when the crowds came to Jesus for healing: "that evening, at sundown" (Mark 1:32). The second step_-"at sundown"-explains that the Sabbath was over, and people could travel to Jesus for healing without violating sabbath laws (Rhoads et al. 2012, p. 49). The poor widow who put two copper coins in the treasury "put in everything she had, all she had to live on" (Mark 12:44). The second step clarifies the first. Not only did she put all she had into the treasury at that moment; she put everything she had to live on as an offering. On series of two in Mark see Neirynck (1988).

A series of three may indicate that an action is complete, finished (Resseguie 2005, p. 49). There may be an intensification of an action from one occurrence to the next, with the third in a series representing a climax. In Matthew's account of Peter's denial each occurrence is progressively intensified. In the first denial, Peter denies knowing what the servant-girl is talking about when he is questioned (Matt. 26:70). In the second, his denial is more forceful with an oath sworn: "I do not know the man" (Matt. 26:72). In the third, his denial is complete. He invokes a curse on himself as well as taking on an oath (Matt. 26:74). The three steps leave no doubt that he has completely abandoned Jesus.

Other threes are important. In the Garden of Gethsemane, the disciples are found to be asleep three times during a time of trial (Mark 14:37, 40, 41). Jesus asks Peter three times if he loves him (John 21:15-17). Three temptations of Jesus are found in Matthew and Luke (Matt. 4:1-11; Luke 4:1-13). Three predictions of Jesus's passion are found in the Synoptic Gospels (Mark 8:31-33; 9:30-32; 10:32-34, and parallels). In the Fourth Gospel, Pilate declares three times that he finds "no case against [Jesus]" (John 18:38b; 19:4, 6). In Acts, Peter is commanded to eat three times (Acts 10:13, 15, 16). In the book of Revelation, sequences of threes describe God's action and being. God's eternity is underscored with 
threes: "who is and who was and who is to come" (Rev. 1:4). Threes describe God's work as Creator: "who created heaven and what is in it, the earth and what is in it, and the sea and what is in it" (Rev. 10:6).

setting: "Setting" is the background of a narrative-the historical, physical, socio-cultural, religious, economic, and temporal circumstances in which the action of the narrative occurs. Setting contributes to the mood of a narrative (Chatman 1978, p. 141), or enlarges the traits of a character, or enhances the development of a plot and its conflicts. The historical setting of the New Testament is the Roman occupation of the first century Mediterranean world. Physical settings include topographical landscape (desert or wilderness; river; lake; sea; mountain; road or way); architectural landscape (temple; house; synagogue; marketplace; garden; sheepfold; tomb; well; praetorium; cities); and geographical landscape (Judea; Samaria; Galilee; "the other side" in Mark 5:1). Socio-cultural settings include meals, rich, poor, "sinners", leaders, tax collectors, pharisees, sadducees, priests, unclean (lepers), women, children, disabled (lame, crippled, blind), soldiers, centurions. Religious settings include special days and feasts (Sabbath, Passover, Tabernacles).

The desert or wilderness is the "fierce landscape" of solace and peril (Lane 1998). The harsh, feral setting of the desert is a place of testing that reveals one's resolve (Resseguie 2004, pp. 12-16; Resseguie 2005, pp. 95-97). For example, Jesus's loyalties are tested in the unreceptive landscape of the desert. Will he follow a false god and receive "the kingdoms of the world and [their] splendor" (Matt. 4:8, Luke 4:5-6)? Or will he remain faithful to the Lord God? Yet this unreceptive terrain is also a place of solace and divine succor ("the angels waited on him," Mark 1:13). The desert or wilderness is also in-between landscape; it is neither here, nor there. It is liminal space. This significance is derived from the Israelites' experience in the desert during their exodus out of Egypt. On the one hand, they are no longer slaves in Egypt; on the other, they are not yet free in the promised land. They are in-between captivity and freedom, between enslavement and a new life. As in-between space, the desert setting plays an important part in the plot of the book of Revelation. In Revelation 12, a woman clothed with the sun, the moon under her feet, and a crown of twelve stars is pursued or persecuted by the great dragon (Rev. 12:1,13). But she is given two wings of a great eagle and flees to the desert where she receives divine solace during the in-between times (one thousand two hundred sixty days or a time, and times, and half a time; see below under temporal settings). The persecuted woman and her children are images of the Christian community (Rev. 12:17); the "great dragon" or Satan is the bloodthirsty pharaoh of Revelation who seeks to destroy the Christian community; and the desert or wilderness is a symbolic place of solace and divine protection for the Christian community during the time between Christ's exaltation and his return at the end of times (Resseguie 2009, pp. 171, 175-76).

Props—sometimes called mise en scène - may take on a significance of their own, enlarging the traits of characters, adding important details to the plot, and signaling transitions in a character's social and spiritual life. In the gospels, props include a water jar, purification water jars, clothing, perfumed spices, charcoal fire, a judge's bench, an untorn net, sop, and so forth. For example, a charcoal fire (anthrakia), which occurs only twice in the New Testament, is the setting for both Peter's denial of Jesus (John 18:18) and his restoration at the Sea of Tiberias (John 21:9). The reader is to recall both settings when analyzing Peter's characterization.

Clothing marks transitions in one's social or spiritual life. In Luke 15:22, the prodigal son receives the best robe, sandals for his feet, and a ring-emblematic of his transition from alienation to new life. Clothing also symbolizes a demoniac's transition from bondage and enslavement by evil powers to new life. Before his exorcism the demoniac in Luke is stark naked like an animal; afterwards he receives once more his humanity and puts on clothes.

For a long time he had worn no clothes (Luke 8: 27).

They found the man from whom the demons had gone sitting at the feet of Jesus, clothed, and in his right mind (Luke 8: 35). 
Clothing reveals the inner landscape of a character-her or his values, commitments, inclinations, motivations, and desires. An interesting example is a man who arrives at a wedding feast without a formal wedding garment (Matt. 22:11-14). When he arrives, the king is incredulous because of his negligence: "Friend, how did you get in here without a wedding robe?" (Matt. 22:12). By arriving at the wedding in his work clothes rather than a wedding robe, he flouts conventions. The king then has him bound hand and foot and cast into outer darkness. Clothing or its lack is important to the plot of this parable, for it is an outward sign that reveals the guest's true colors. A festal occasion requires a festal garment; but the invitee breaks with the norms and conventions of the day and appears in soiled work clothes (Bauckham 1996, p. 485; Olmstead 2003, p. 126). "For any such occasion guests would be expected to wear clothes that were both longer than those worn by ordinary working people on working days and also newly washed" (Bauckham 1996, p. 485). In the parable, clothing announces the desires and inclinations of this guest, he does not want to be there. Although he is present at the party, he is absent in other ways. Since this is not the party for him, the king fulfills his wishes and sends him on his way to another party, one in outer darkness, where the guests celebrate with the weeping and gnashing of teeth (Resseguie 2005, p. 106).

An abandoned water jar (hydria) would appear to be "a narratively unnecessary detail" that readers could easily skip over (Schneiders 1999, p. 192). Yet the prop raises questions about why the narrator records something so minor. The abandoned jar occurs in the story of the Samaritan woman who encounters Jesus at Jacob's well: "Then the woman left her water jar and went back to the city" (John 4:28). Could it be that she left the water jar for Jesus to draw water? Or did she leave the bucket behind because she intended to return to the well with the villagers? (O'Day 1986, p. 75). Or perhaps she was in such a hurry to tell the villagers about Jesus that she simply forgot the jar? Or does the water jar have symbolic significance? If symbolic, does it symbolize the woman's freedom from "her entire oppression" (Schottroff 1998, pp. 160,174). Schottroff argues that she is no longer in bondage with the man she is living with and no longer bound by the tasks that woman normally do in that society, such as fetching water. Or is the symbolism to be found in the equivalent action of the male disciples who abandon their fishing nets? (Schneiders 1999, p. 192). Like the disciples, she abandons her past to follow Jesus; water jars and fishing nets are no longer needed for this new adventure. Perhaps, the symbolism is to be found in the kind of water she has now found. The woman leaves the water jar behind because it is worthless for "living water" (Brown 1966, p. 173; Lee 1994, pp. 84-85; Koester 2003, pp. 190-91; Culpepper 1983, p. 194; Boers 1988, pp. 182-83). Whatever the explanation, the abandoned water jar is the type of prop that keeps the reader engaged in the narrative and searching for answers.

Another type of prop is a MacGuffin, a term popularized by Alfred Hitchcock, although the term precedes Hitchcock's usage of it (Harmon 2012, p. 283). It is an object, event, or character that serves as a motivator for the plot (Chatman 1978, p. 140). Although the MacGuffin may be insignificant, even a gimmick, it is necessary to move the plot forward (Harmon 2012, p. 283) and, although it is frequently mysterious and unexplained, it is something the characters care about. For example, the falcon statuette in the movie, The Maltese Falcon (1941), is an object that the characters pursue in earnest, becoming a device that moves the action forward to its dénouement. In the film, Raiders of the Lost Arc (1981), the protagonist, Indiana Jones, is in pursuit of a MacGuffin — the ark of the covenant-that the antagonists (the Nazis) are also in search of. In the parable of the guest who arrives without a wedding robe (Matt. 22:11-14 above), the wedding gown is a MacGuffin that is important for the plot. Yet it is never explained why it is essential for the guest to have a special robe or even why the guest's oversight should result in such drastic consequences, but clearly it is something the characters care about or should care about. In Revelation 10, a mighty angel holds a MacGuffin in his hand-an opened scroll—that is important for the plot's dénouement. The scroll is a mysterious and unexplained object that John cares about for he devours its contents, which are sweet as honey in his mouth but bitter in his stomach (Rev. 10:10). With the last trumpet plague (Rev. 9), the plot of Revelation has come to a complete standstill. But the MacGuffin-scroll moves the plot forward. Whereas the plagues were 
ineffective in persuading the stolid to abandon their wicked ways (Rev. 9:20-21), the MacGuffin-scroll advances the plot to its dénouement. The suffering and prophetic witness of the Christian community now accomplishes what the plagues alone were unable to effect. Their actions persuade the recalcitrant to give glory to God (Resseguie forthcoming (b) Narrative Features"; Koester 2014, p. 505; Mounce 1998, p. 210; Charles 1920, 1:260; Mazzaferri 1989, pp. 267-69).

Temporal settings are either chronological or typological (Powell 1990, pp. 72-74). Chronological references refer to the time an action takes place: the disciples are to take up their cross "daily" (Luke 9:23); a rich man feasts "every day" (Luke 16:19); the Beroeans examine the scriptures "every day" (Acts 17:11). In Mark 13:18, the disciples are to pray that the end-time tribulation not occur in winter. Matthew, however, includes another temporal setting that he considers important: "Pray that your flight may not be in winter or on a sabbath" (Matt. 24:20). The small detail gives the reader a glimpse into Matthew's social setting.

Typological settings, on the other hand, indicate the kind of time in which an action takes place and are often symbolic. In John, a nighttime setting is more than background atmosphere; it is saturated with meaning. Darkness may symbolize opacity or represent a character's abandonment of the light for darkness. Nicodemus comes to Jesus "by night," (John 3:2), which describes not only the time of day but also Nicodemus' lack of understanding. "It was night" when Judas leaves the Last Supper to hand Jesus over to the authorities (John 13:30). The nighttime setting is symbolic: he goes out at night to join the powers of darkness in their cabal against Jesus. In Revelation 20, the millennium is a kind of time- - not the actual length of time. The symbolic one thousand years is a Satan-free period in which the saints reign. The kind of time is expressed by several other temporal settings in Revelation: (1) a time, and times, and half a time (=three and a half times or years, Rev. 12:14); (2) one thousand two hundred and sixty days (=three and a half years, Rev. 11:3; 12:6); (3) forty-two months (=three and a half years or forty-two months of thirty days, Rev. 11:2; 13:5); and (4) three and a half days (Rev. 11:9, 11). The temporal notations are numerical ciphers for the "in-between times" - that is, the period between Jesus's ascension and exaltation and his return at the end of time (Koester 2014, p. 498). This kind of time is a period of peril and solace: intense but limited persecution on the one hand, and divine protection on the other (Resseguie forthcoming (b) "Narrative Features").

showing (in narrative) $\rightarrow$ characterization.

simile and metaphor: Similes compare two distinctly different things with the use of "like" or "as." The parable of the leaven in Matt. 13:33 is a simile. "The kingdom of heaven is like yeast that a woman took and mixed in three measures of flour, till it was leavened". On the other hand, a metaphor does not state explicitly a comparison between two distinctly different things. Rather it ascribes an action or quality of one thing to a second by way of identity. Jesus's statements "I am the bread of life" and "I am the light of the world" are metaphors that ascribe two different qualities (light and bread) to Jesus by way of identity.

I. A. Richards uses the concepts of tenor and vehicle to analyze metaphors (Richards 1936, pp. 119-27). The tenor is the subject of the comparison and the vehicle is the image. To phrase it differently, the vehicle is the image that illumines the tenor-the subject of the metaphor. The vehicle and tenor make up the metaphor, and the reader must identify the comparison that exists between the two parts. The following saying from Matthew illustrates the importance of Richards' concepts. "Wherever the corpse is, there the vultures will gather" (Matt. 24:28). The tenor is not specified and can only be gleaned from the context itself. Nevertheless, the vehicle-the imagery of vultures and carcasses-should be analyzed before identifying the tenor. When one sees vultures circling above, a carcass is certain to be found below. The implicit metaphor-a metaphor that does not specify the tenor-is solved by an examination of the context in Matthew 24. The tenor is the coming of the Son of Man again. In the end times false messiahs and false prophets will appear that will "produce great signs and omens, to lead [people] astray" (Matt. 24:24). Some will be swayed by counterfeit messiahs and prophets' appearance that claim that the Messiah has appeared in secret-for example, in the wilderness or in inner rooms (Matt. 24:26). The question the metaphor addresses is: Will the Son of 
Man's appearance be in secret or will it be unmistakable? The vehicle (vultures and carcasses) suggests that the coming of the Son of Man will be as apparent as birds of prey circling in the sky announces a carcass below. Matthew reinforces this comparison with a simile: "For as the lightning comes from the east and flashes as far as the west, so will be the coming of the Son of Man" (Matt. 24:27).

situational irony $\rightarrow$ irony.

static character $\rightarrow$ character.

stock character $\rightarrow$ character.

story and discourse: "Story and discourse" are terms used by Seymour Chatman to describe the necessary components of a narrative: the what and the how. The story or the what is its content such as actions, happenings, characters, and setting. The discourse or the how is "the means by which the content is communicated" (Chatman 1978, p. 19). Narrative critics generally ask the same questions as Chatman: (1) What is the narrative about? and (2) How is the story told or how is its content communicated? The four gospels-Matthew, Mark, Luke, and John-illustrate the importance of analyzing story and discourse. Although there is considerable overlap in the narrative content of the gospels (the story), the way the stories are told (the discourse) is distinctive to each writer (Malbon 2008, p. 32).

stream of consciousness $\rightarrow$ character (interior monologue).

synonymous parallelism $\rightarrow$ parallelism.

syuzhet (in Russian formalism) $\rightarrow$ defamiliarization.

telling (in narrative) $\rightarrow$ characterization.

trope $\rightarrow$ rhetoric.

two-step progression $\rightarrow$ sequence of action.

type-scene: A "type-scene" is a recurrent motif that is recognized by the reader as conventional. Robert Alter drew upon Homer to develop the concept of type-scenes in biblical literature. They are common stories that are "dependent on the manipulation of a fixed constellation of pre-determined motifs" (Alter 1981, p. 51). For example, betrothal scenes in the Hebrew Bible have the following recurrent motifs:

(1) A future bridegroom travels to a foreign land.

(2) He encounters a girl or girls at a well.

(3) The girl(s) rush home to bring news of the stranger's arrival.

(4) A betrothal is concluded between the stranger and the girl, often involving a meal (Alter 1981, p. 52).

The variations in the betrothal type-scenes add to the artistry of individual scenes and draw attention to important words, motifs, themes, and characters. Examples of betrothal type-scenes in the Hebrew Bible are: the encounter between Abraham's servant and Rebekah (Genesis 24:10-61); Jacob's encounter at the well with Rachel (Genesis 29:1-20); Moses and Zipporah (Exodus 2:15b-21); and the book of Ruth.

In John 4, Jesus's encounter with the woman at the well is a betrothal type-scene, though a betrothal of a very different kind- "not in marriage but in worship (4:21-24) and in mission (4:35-42)" (Black 2001, p. 17). Other type-scenes include the annunciation of a hero's birth (Alter 1983); trial/temptation in the wilderness; danger and rescue on the sea; healing miracles; exorcisms; meal scenes; and recognition type-scenes (Resseguie 2005, pp. 53-54; Rhoads et al. 2012, p. 51).

The most extensive study of type-scenes in the New Testament is found in Kasper Bro Larsen's monograph, Recognizing the Stranger (2008), which explores recognition (anagnorisis) scenes in the Fourth Gospel. Like Alter, Larsen draws upon Homer's Odyssey for his analysis of type-scenes-especially the famous bath-scene in which Eurycleia, Odysseus' childhood nurse, gives 
him a bath and recognizes the boar-hunt scar on his thigh from early days (Homer 2017, Book 19). Although Odysseus attempts to conceal his identity from Penelope, his beloved, and Eurycleia, the secret is revealed in this moment of tearful recognition. Larsen identifies five "typical moves" found in recognition scenes (Larsen 2008, pp. 63, 219-20).

(1) The meeting.

(2) Cognitive resistance in which doubts are raised or requests of proof are made.

(3) A token of recognition is displayed.

(4) The moment of recognition.

(5) Attendant reactions and physical (re-)union.

Larsen notes that not all moves are present in every recognition scene, and, like Alter, he concludes that variations in type-scenes amplify themes and motifs of individual narratives. Some of the recognition scenes that Larsen develops are: the Samaritan woman (John 4), the man born blind (John 9), Peter's denial (John 18:15-18, 25-27), Mary Magdalene (John 20:11-18), and Thomas (John 20:26-29).

un-intrusive narrator $\rightarrow$ narrator.

unreliable narrator $\rightarrow$ characterization and narrator.

unspoken soliloquy $\rightarrow$ character.

U-shaped plot or inverted U-shaped plot $\rightarrow$ plot.

vehicle and tenor $\rightarrow$ simile and metaphor.

verbal irony $\rightarrow$ irony.

verbal thread: "Verbal threads" are repeated words or phrases that may link together episodes and draw the reader's attention to disparate narratives. For example, the word for "charcoal fire" (anthrakia) occurs only twice in the New Testament, both times in the Fourth Gospel (John 18:18; 21:9). When Peter enters the high priest's courtyard, he joins the posse that just arrested Jesus, and warms himself by the charcoal fire (John 18:18). The memorable setting is the backdrop for his threefold denial of Jesus. The second occurrence of anthrakia occurs in John 21:9 when Jesus invites the disciples to eat a meal of bread and fish, cooked on a charcoal fire. Shortly after this scene, Peter professes his love for Jesus three times. The verbal thread ties together two separate events involving the same characters, Jesus and Peter, and encourages the reader to ponder the connection between the events (Resseguie 2005, pp. 42-45).

walk-on $\rightarrow$ character.

Funding: This research received no external funding.

Conflicts of Interest: The author declares no conflict of interest.

\section{References}

Abbott, H. Porter. 2008. The Cambridge Introduction to Narrative, 2nd ed. Cambridge Introductions to Literature. Cambridge: Cambridge University Press.

Abrams, Meyer H., and Geoffrey Galt Harpham. 2015. A Glossary of Literary Terms, 11th ed. Stamford: Cengage Learning.

Alter, Robert. 1981. The Art of Biblical Narrative. New York: Basic Books.

Alter, Robert. 1983. How Convention Helps Us Read: The Case of the Bible's Annunciation Type-Scenes. Prooftexts 3: $115-30$.

Anderson, Janice Capel. 1983. Matthew, Gender and Reading. Semeia 28: 3-28.

Anderson, Janice Capel, and Stephen D. Moore. 2008. Mark and Method: New Approaches in Biblical Studies, 2nd ed. Minneapolis: Fortress Press.

Aristotle. 1995. Poetics. Loeb Classical Library 199. Edited and translated by Stephen Halliwell. Cambridge: Harvard University Press. 
Arp, Thomas R., and Greg Johnson. 2017. Perrine's Story and Structure, 15th ed. Boston: Wadsworth Cengage Learning.

Austin, Jane. 2001. Pride and Prejudice, 3rd ed. Edited by Donald Gray. New York: W. W. Norton. First published 1813. Bakhtin, Mikhail. 1984. Problems of Dostoevsky's Poetics. Theory and History of Literature. Edited and translated by Caryl Emerson. Minneapolis: University of Minnesota Press, vol. 8.

Bal, Mieke. 2009. Narratology: Introduction to the Theory of Narrative, 3rd ed. Translated by Christine van Boheeman. Toronto: University of Toronto Press.

Barr, David L. 1998. Tales of the End: A Narrative Commentary on the Book of Revelation. Santa Rosa: Polebridge Press.

Barr, David L. 2016. Narrative Technique in the Book of Revelation. In Oxford Handbook of Biblical Narrative. Edited by Danna Nolan Fewell. Oxford: Oxford University Press, pp. 376-88.

Barrett, C. K. 1978. The Gospel According to St. John: An Introduction with Commentary and Notes on the Greek Text, 2nd ed. Westminster: Philadelphia.

Barthes, Roland. 1974. S/Z: An Essay. Translated by Richard Miller. New York: Hill and Wang.

Bauckham, Richard. 1996. The Parable of the Royal Wedding Feast (Matthew 22:1-14) and the Parable of the Lame Man and the Blind Man (Apocryphon of Ezekiel). Journal of Biblical Literature 115: 471-88. [CrossRef]

Bernard, J. H. 1929. A Critical and Exegetical Commentary on the Gospel according to St. John. 2 vols. New York: Scribner's.

Black, C. Clifton. 2001. The Rhetoric of the Gospel: Theological Artistry in the Gospels and Acts. St. Louis: Chalice.

Bleich, David. 1975. Readers and Feelings: An Introduction to Subjective Criticism. Urbana: National Council of Teachers of English.

Boers, Hendrikus. 1988. Neither on This Mountain nor in Jerusalem: A Study of John 4. Society of Biblical Literature Monograph Series 35. Atlanta: Scholars Press.

Boesak, Allan A. 1987. Comfort and Protest: Reflections on the Apocalypse of John of Patmos. Philadelphia: Westminster Press. Booth, Wayne C. 1983. The Rhetoric of Fiction, 2nd ed. Chicago: University of Chicago Press.

Brown, Raymond E. 1966. The Gospel according to John I-XII. Anchor Yale Bible 29. New Haven: Yale University Press. Bultmann, Rudolf. 1971. The Gospel of John: A Commentary. Translated by G. R. Beasley-Murray. Philadelphia: Westminster.

Camery-Hoggatt, Jerry. 1992. Irony in Mark's Gospel: Text and Subtext. Society for New Testament Studies Monograph Series 72. Cambridge: Cambridge University Press.

Carter, Warren. 2004. Matthew: Storyteller, Interpreter, Evangelist, rev. ed. Grand Rapids: Baker Academic.

Castelli, Elizabeth A., Stephen D. Moore, Gary A. Phillips, and Regina M. Schwartz, eds. 1995. Reader-Response Criticism. In The Postmodern Bible. The Bible and Culture Collective. New Haven: Yale University Press, pp. 20-69.

Charles, R. H. 1920. A Critical and Exegetical Commentary on the Revelation of St. John. 2 vols. International Critical Commentary. New York: Scribner's.

Chatman, Seymour. 1978. Story and Discourse: Narrative Structure in Fiction and Film. Ithaca: Cornell University Press.

Childs, Peter, and Roger Fowler. 2006. The Routledge Dictionary of Literary Terms. London: Routledge.

Coleridge, Samuel Taylor. 1983. Biographia Literaria or Biographical Sketches of My Literary Life and Opinions. Bollingen Series 75; Edited by James Engell and W. Jackson Bate. Princeton: Princeton University Press. First published 1817.

Culpepper, R. Alan. 1983. Anatomy of the Fourth Gospel: A Study in Literary Design. Philadelphia: Fortress Press.

Darr, John A. 1992. On Character Building: The Reader and the Rhetoric of Characterization in Luke-Acts. Literary Currents in Biblical Interpretation. Louisville: Westminster John Knox Press.

Darr, John A. 1998. Herod the Fox: Audience Criticism and Lukan Characterization. Journal for the Study of the New Testament Supplement Series 163. Sheffield: Sheffield Academic Press.

Dawsey, James M. 1986. What's in a Name: Characterization in Luke. Biblical Theology Bulletin 16: 143-47. [CrossRef]

Dicken, Frank E. 2014. Herod as a Composite Character in Luke-Acts. Wissenschaftliche Untersuchungen zum Neuen Testament II 375. Tübingen: Mohr Siebeck.

Dicken, Frank E., and Julia A. Snyder, eds. 2016. Characters and Characterization in Luke-Acts. Library of New Testament Studies 548. London: Bloomsbury T \& T Clark.

Dinkler, Michal Beth. 2013. Silent Statements: Narrative Representations of Speech and Silence in the Gospel of Luke. Beihefte zur Zeitschrift für die neutestamentliche Wissenschaft 191. Berlin: De Gruyter. 
Dinkler, Michal Beth. 2015. 'The Thoughts of Many Hearts Shall be Revealed': Listening in on Lukan Interior Monologues. Journal of Biblical Literature 134: 373-99.

Dinkler, Michal Beth. 2017. Building Character on the Road to Emmaus: Lukan Characterization in Contemporary Literary Perspective. Journal of Biblical Literature 136: 687-706. [CrossRef]

Docherty, Thomas. 1983. Reading (Absent) Character: Towards a Theory of Characterization in Fiction. Oxford: Clarendon.

Duke, Paul. 1985. Irony in the Fourth Gospel. Atlanta: John Knox Press.

Edwards, James R. 1989. Markan Sandwiches: The Significance of Interpolations in Markan Narratives. Novum Testamentum 31: 193-216.

Elliot, Scott S. 2011. Reconfiguring Mark's Jesus: Narrative Criticism after Poststructuralism. The Bible in the Modern World 41. Sheffield: Sheffield Phoenix Press.

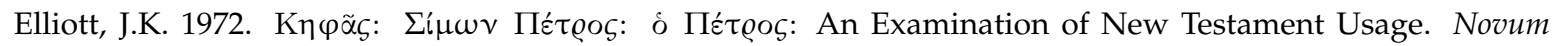
Testamentum 14: 241-56.

Finnern, Sönke. 2010. Narratologie und Biblische Exegese: Eine integrative Methode der Erzählanalyse und ihr Ertrag am Beispiel von Matthäus 28. Wissenschaftliche Untersuchungen zum Neuen Testament 285. Tübingen: Mohr Siebeck.

Finnern, Sönke. 2014. Narration in Religious Discourse: The Example of Christianity. In The Living Handbook of Narratology. Edited by Peter Hühn, Jan Christoph Meister, John Pier and Wolf Schmid. Hamburg: Hamburg University. Available online: http://www.lhn.uni-hamburg.de/article/narration-religiousdiscourse-example-christianity (accessed on 18 March 2019).

Fish, Stanley E. 1980. Is There a Text in This Class? The Authority of Interpretative Communities. Cambridge: Harvard University Press.

Fishbane, Michael. 1979. Text and Texture: Close Readings of Selected Biblical Texts. New York: Schocken Books.

Forster, Edward M. 2005. Aspects of the Novel. New York: Penguin Books. First published 1927.

Fowler, Robert M. 1991. Let the Reader Understand: Reader-Response Criticism and the Gospel of Mark. Minneapolis: Fortress Press.

Fowler, Robert M. 2008. Reader-Response Criticism: Figuring Mark's Reader. In Mark and Method: Approaches in Biblical Studies, 2nd ed. Edited by Janice Capel Anderson and Stephen D. Moore. Minneapolis: Fortress, pp. 59-93.

Freytag, Gustav. 1896. Freytag's Technique of the Drama: An Exposition of Dramatic Composition and Art, 2nd ed. Translated by Elias J. MacEvan. Chicago: S. G. Briggs and Company.

Frye, Northrop. 1981. The Great Code: The Bible and Literature. New York: Harcourt Brace Jovanovich.

Genette, Gérard. 1980. Narrative Discourse: An Essay in Method. Translated by Jane E. Lewin. Ithaca: Cornell University Press. First published 1972.

Gombrich, E. H. 1961. Art and Illusion: A Study in the Psychology of Pictorial Representation, 2nd ed. revised. Bollingen Series 35. Princeton: Princeton University Press.

Goodman, Paul. 1954. The Structure of Literature. Chicago: University of Chicago Press.

Green, Joel B. 2016. A Cognitive Narratological Approach to the Characterization(s) of Zacchaeus. In Characters and Characterization in Luke-Acts. Library of New Testament Studies 548. Edited by Frank E. Dicken and Julia A. Snyder. London: Bloomsbury T \& T Clark, pp. 109-20.

Harmon, William. 2012. A Handbook to Literature, Twelfth Edition ed. Boston: Longman.

Herman, David. 2013. Cognitive Narratology. In The Living Handbook of Narratology. Edited by Peter Hühn, Jan Christoph Meister, John Pier and Wolf Schmid. Hamburg: Hamburg University. Available online: http:/ /www.lhn.uni-hamburg.de/article/cognitive-narratology-revised-version-uploaded-22september-2013 (accessed on 18 March 2019).

Hochman, Baruch. 1985. Character in Literature. Ithaca: Cornell University Press.

Holland, Norman N. 1975a. 5 Readers Reading. New Haven: Yale University Press.

Holland, Norman N. 1975b. Unity Identity Text Self. Publications of the Modern Language Association 90: 813-22. [CrossRef]

Homer. 2017. The Odyssey. Translated by Emily Wilson. New York: W. W. Norton \& Company.

Hongisto, Leif. 2010. Experiencing the Apocalypse at the Limits of Alterity. Biblical Interpretation Series 102. Leiden: Brill. Horsley, Richard A. 2001. Hearing the Whole Story: The Politics of Plot in Mark's Gospel. Louisville: Westminster John Knox.

Howell, David B. 1990. Matthew's Inclusive Story: A Study of the Narrative Rhetoric of the First Gospel. Journal for the Study of New Testament Supplement Series 42. Sheffield: JSOT Press. 
Hunt, Steven A., D. Francois Tolmie, and Ruben Zimmermann, eds. 2013. Character Studies in the Fourth Gospel: Narrative Approaches to Seventy Figures in John. Wissenschaftliche Untersuchungen zum Neuen Testament 314. Tübingen: Mohr Siebeck; reprint. Grand Rapids, MI: Eerdmans, 2016.

Iser, Wolfgang. 1971. Indeterminacy and the Reader's Response in Prose Fiction. In Aspects of Narrative. Edited by J. Hillis Miller. New York: Columbia University Press, pp. 1-45.

Iser, Wolfgang. 1972. The Reading Process: A Phenomenological Approach. New Literary History: A Journal of Theory and Interpretation 3: 279-99. [CrossRef]

Iser, Wolfgang. 1974. The Implied Reader: Patterns of Communication in Prose Fiction from Bunyan to Beckett. Baltimore: Johns Hopkins University Press.

Iser, Wolfgang. 1978. The Act of Reading: A Theory of Aesthetic Response. Baltimore: Johns Hopkins University Press. James, Henry. 1948. The Art of Fiction. In The Art of Fiction and Other Essays by Henry James. Edited by Morris Roberts. New York: Oxford University Press, pp. 3-23. First published 1884.

Kermode, Frank. 1979. The Genesis of Secrecy: On the Interpretation of Narrative. The Charles Elliot Norton Lectures 35. Cambridge: Harvard University Press.

Kingsbury, Jack Dean. 1991. Matthew: Structure, Christology, Kingdom. Minneapolis: Fortress Press.

Koester, Craig R. 2003. Symbolism in the Fourth Gospel: Meaning, Mystery, Community, 2nd ed. Minneapolis: Fortress Press. Koester, Craig R. 2014. Revelation. Anchor Yale Bible 38A. New Haven: Yale University Press.

Kurz, William S. 1993. Reading Luke-Acts: Dynamics of Biblical Narrative. Louisville: Westminster John Knox Press. Lane, Belden C. 1998. The Solace of Fierce Landscapes: Exploring Desert and Mountain Spirituality. New York: Oxford University Press.

Lanser, Susan Sniader. 1981. The Narrative Act: Point of View in Prose Fiction. Princeton: Princeton University Press. Larsen, Kasper Bro. 2008. Recognizing the Stranger: Recognition Scenes in the Gospel of John. Biblical Interpretation Series 93. Leiden: Brill.

Lee, Dorothy A. 1994. The Symbolic Narratives of the Fourth Gospel: The Interplay of Form and Function. Journal for the Study of the New Testament Supplement Series 95. Sheffield: JSOT Press.

Lehtipuu, Outi. 1999. Characterization and Persuasion: The Rich Man and the Poor Man in Luke 16, 19-31. In Characterization in the Gospels: Reconceiving Narrative Criticism. Journal for the Study of the New Testament Supplement Series 184; Edited by David Rhoads and Kari Syreeni. Sheffield: Sheffield Academic Press, pp. 73-105.

Mailloux, Steven. 1982. Interpretive Conventions: The Reader in the Study of American Fiction. Ithaca: Cornell University Press.

Malbon, Elizabeth Struthers. 1983. Fallible Followers: Women and Men in the Gospel of Mark. Semeia 28: $29-48$.

Malbon, Elizabeth Struthers. 2000. In the Company of Jesus: Characters in Mark's Gospel. Louisville: Westminster John Knox Press.

Malbon, Elizabeth Struthers. 2008. Narrative Criticism: How Does the Story Mean? In Mark \& Method: New Approaches in Biblical Studies, 2nd ed. Edited by Janice Capel Anderson and Stephen D. Moore. Minneapolis: Fortress Press, pp. 29-57.

Malbon, Elizabeth Struthers. 2009. Mark's Jesus: Characterization as Narrative Christology. Waco: Baylor University Press.

Malbon, Elizabeth Struthers. 2011. Characters in Mark's Story: Changing Perspectives on the Narrative Process. In Mark as Story: Retrospect and Prospect. Resources for Biblical Study 65. Edited by Kelly R. Iverson and Christopher W. Skinner. Atlanta: Society of Biblical Literature, pp. 45-69.

Marguerat, Daniel, and Yvan Bourquin. 1999. How to Read Bible Stories: An Introduction to Narrative Criticism. London: SCM Press.

Martin, Wallace. 1986. Recent Theories of Narrative. Ithaca: Cornell University Press.

Matera, Frank J. 1987. The Plot of Matthew's Gospel. Catholic Biblical Quarterly 49: 233-53.

Mazzaferri, Frederick David. 1989. The Genre of the Book of Revelation from a Source-Critical Perspective. Beiheft zur Zeitschrift für die neutestamentliche Wissenschaft und die Kunde der älteren Kirche 54. Berlin: de Gruyter.

Meister, Jan Christoph. 2014. Narratology. In The Living Handbook of Narratology. Edited by Peter Hühn, Jan Christoph Meister, John Pier and Wolf Schmid. Hamburg: Hamburg University. Available online: http:/ / www.lhn.uni-hamburg.de/article/narratology (accessed on 18 March 2019).

Moore, Stephen D. 1989. Literary Criticism and the Gospels: The Theoretical Challenge. New Haven: Yale University Press. 
Moore, Stephen D. 2016. Biblical Narrative Analysis from the New Criticism to the New Narratology. In The Oxford Handbook of Biblical Narrative. Edited by Danna Nolan Fewell. New York: Oxford University Press, pp. 27-50.

Mounce, Robert H. 1998. The Book of Revelation, rev. ed. New International Commentary on the New Testament. Grand Rapids: Eerdmans.

Muecke, D. C. 1969. The Compass of Irony. London: Methuen.

Neirynck, Frans. 1988. Duality in Mark: Contributions to the Study of the Markan Redaction, rev. ed. Bibliotheca Ephemeridum Theologicarum Lovaniensium 31. Louvain: Louvain University Press.

Niederhoff, Burkhard. 2013a. Focalization. In The Living Handbook of Narratology. Edited by Peter Hühn, Jan Christoph Meister, John Pier and Wolf Schmid. Hamburg: Hamburg University. Available online: http:/ / www.lhn.uni-hamburg.de/article/focalization (accessed on 18 March 2019).

Niederhoff, Burkhard. 2013b. Perspective-Point of View. In The Living Handbook of Narratology. Edited by Peter Hühn, Jan Christoph Meister, John Pier and Wolf Schmid. Hamburg: Hamburg University. Available online: http:/ / www.lhn.uni-hamburg.de/article/perspective----point-view (accessed on 18 March 2019).

O’Day, Gail. 1986. Revelation in the Fourth Gospel: Narrative Mode and Theological Claims. Philadelphia: Fortress Press.

Olmstead, Wesley G. 2003. Matthew's Trilogy of Parables: The Nation, the Nations, and the Reader in Matthew 21:28-22:14. Society for New Testament Studies Monograph Series 127. Cambridge: Cambridge University Press.

Perry, Menakhem. 1979. Literary Dynamics: How the Order of a Text Creates Its Meanings. Poetics Today 1: 35-64, 311-61. [CrossRef]

Phelan, James. 2005a. Living to Tell about It: A Rhetoric and Ethics of Character Narration. Ithaca: Cornell University Press.

Phelan, James. 2005b. Rhetorical Narratology. In Routledge Encyclopedia of Narrative Theory. Edited by David Herman, Manfred Jahn and Marie-Laure Ryan. London: Routledge, pp. 500-4.

Powell, Mark Allan. 1990. What is Narrative Criticism? Guides to Biblical Scholarship, New Testament Series. Minneapolis: Fortress Press.

Powell, Mark Allan. 2001. Chasing the Eastern Star: Adventures in Biblical Reader-Response Criticism. Louisville: Westminster John Knox Press.

Powell, Mark Allan. 2011. Narrative Criticism: The Emergence of a Prominent Reading Strategy. In Mark as Story: Retrospect and Prospect. Resources for Biblical Study 65. Edited by Kelly R. Iverson and Christopher W. Skinner. Atlanta: Society of Biblical Literature, pp. 19-43.

Prince, Gerald. 1971. Notes toward a Characterization of Fictional Narratees. Genre 4: 100-5.

Prince, Gerald. 1973. Introduction to the Study of the Narratee. Poétique 14: 177-96.

Prince, Gerald. 2013. Reader. In The Living Handbook of Narratology. Edited by Peter Hühn, Jan Christoph Meister, John Pier and Wolf Schmid. Hamburg: Hamburg University. Available online: http://www.lhn.unihamburg.de/article/reader (accessed on 18 March 2019).

Rabinowitz, Peter J. 1987. Before Reading: Narrative Conventions and the Politics of Interpretation. Ithaca: Cornell University Press.

Reinhartz, Adele. 2001. Befriending the Beloved Disciple: A Jewish Reading of the Gospel of John. New York: Continuum.

Resseguie, James L. 1982a. John 9: A Literary-Critical Analysis. In Literary Interpretations of Biblical Narratives. Edited by Kenneth R. R. Gros Louis. Nashville: Abingdon Press, vol. 2, pp. 295-303; reprinted in The Gospel of John as Literature: An Anthology of Twentieth-Century Literature, 1993, pp. 115-22.

Resseguie, James L. 1982b. Point of View in the Central Section of the Gospel of Luke (9:51-19:44). Journal of the Evangelical Theological Society 25: 41-47.

Resseguie, James L. 1984. Reader-Response Criticism and the Synoptic Gospels. Journal of the American Academy of Religion 52: 307-24. [CrossRef]

Resseguie, James L. 1988. Defamiliarization in the Gospels. Mosaic: A Journal for the Interdisciplinary Study of Literature 21: 25-35. [CrossRef]

Resseguie, James L. 1990. Defamiliarization and the Gospels. Biblical Theology Bulletin 20: 147-53. [CrossRef]

Resseguie, James L. 1991. Automatization and Defamiliarization in Luke 7:36-50. Journal of Literature and Theology 5: 137-50. [CrossRef]

Resseguie, James L. 1992. Luke 7:36-50. Interpretation: A Journal of Bible and Theology 46: 285-90. [CrossRef] 
Resseguie, James L. 1998. Revelation Unsealed: A Narrative Critical Approach to John's Apocalypse. Biblical Interpretation Series 32; Leiden: Brill.

Resseguie, James L. 2000. Literature, New Testament. In Eerdmans Dictionary of the Bible. Edited by David Noel Freedman. Grand Rapids: Eerdmans, pp. 815-17.

Resseguie, James L. 2001. The Strange Gospel: Narrative Design and Point of View in John. Biblical Interpretation Series 56. Leiden: Brill.

Resseguie, James L. 2004. Spiritual Landscape: Images of the Spiritual Life in the Gospel of Luke. Peabody: Hendrickson. Resseguie, James L. 2005. Narrative Criticism of the New Testament: An Introduction. Grand Rapids: Baker Academic. Resseguie, James L. 2007. Formalist/New Critical Interpretation. In Dictionary of Biblical Criticism and Interpretation. Edited by Stanley E. Porter. New York: Routledge, pp. 114-17.

Resseguie, James L. 2009. The Revelation of John: A Narrative Commentary. Grand Rapids: Baker Academic.

Resseguie, James L. 2013a. The Beloved Disciple: The Ideal Point of View. In Character Studies in the Fourth Gospel: Narrative Approaches to Seventy Figures in John. Wissenschaftliche Untersuchungen zum Neuen Testament 314. Edited by Steven A. Hunt, D. Francois Tolmie and Ruben Zimmermann. Tübingen: Mohr Siebeck, pp. 537-49; reprint, Grand Rapids, MI: Eerdmans, 2016, pp. 537-49.

Resseguie, James L. 2013b. A Narrative-Critical Approach to the Fourth Gospel. In Characters and Characterization in the Gospel of John. Library of New Testament Studies 461. Edited by Christopher W. Skinner. London: Bloomsbury T \& T Clark, pp. 3-17.

Resseguie, James L. 2016. The Woman Who Crashed Simon's Party: A Reader-Response Approach to Luke 7:36-50. In Characters and Characterization in Luke-Acts. Library of New Testament Studies 548. Edited by Frank E. Dicken and Julia A. Snyder. London: Bloomsbury T \& T Clark, pp. 7-22.

Resseguie, James L. Forthcoming (a). Narrative Criticism/Narratology. In Encyclopedia of the Bible and Its Reception. Edited by Christine Helmer, Stephen L. Mackenzie, Thomas Chr Romer, Jen Schroter, Barry Dov Walfish and Eric Ziolkowski. Berlin: de Gruyter.

Resseguie, James L. Forthcoming (b). Narrative Features of the Book of Revelation. In Oxford Handbook of the Book of Revelation. Edited by Craig R. Koester. New York: Oxford University Press.

Rhoads, David. 2004. Jesus and The Syrophoenician Woman in Mark: A Narrative-Critical Study. Journal of the American Academy of Religion 62: 343-75; reprinted in Reading Mark, pp. 63-94. First published 1994. [CrossRef]

Rhoads, David. 1982. Narrative Criticism and the Gospel of Mark. Journal of the American Academy of Religion 50: 411-34. [CrossRef]

Rhoads, David. 2004. Reading Mark: Engaging the Gospel. Minneapolis: Fortress Press.

Rhoads, David, and Donald Michie. 1982. Mark as Story: An Introduction to the Narrative of a Gospel. Minneapolis: Fortress Press.

Rhoads, David, and Kari Syreeni, eds. 1999. Characterization in the Gospels: Reconceiving Narrative Criticism. Journal for the Study of the New Testament Supplement Series 184. Sheffield: Sheffield Academic Press.

Rhoads, David, Joanna Dewey, and Donald Michie. 2012. Mark as Story: An Introduction to the Narrative of a Gospel, 3rd ed. Minneapolis: Fortress Press.

Richards, I. A. 1936. The Philosophy of Rhetoric. New York: Oxford University Press.

Rimmon-Kenan, Shlomith. 2002. Narrative Fiction: Contemporary Poetics (New Accents), 2nd ed. London: Routledge.

Roth, S. John. 1997. The Blind, the Lame and the Poor: Character Types in Luke-Acts. Journal for the Study of the New Testament Supplement Series 144. Sheffield: Sheffield Academic Press.

Schmid, Wolf. 2013. Narratee. In The Living Handbook of Narratology. Edited by Peter Hühn, Jan Christoph Meister, John Pier and Wolf Schmid. Hamburg: Hamburg University. Available online: http://www.lhn.unihamburg.de/article/narratee (accessed on 18 March 2019).

Schneiders, Sandra M. 1999. The Revelatory Text: Interpreting the New Testament as Sacred Scripture, 2nd ed. Collegeville: The Liturgical Press.

Scholes, Robert, James Phelan, and Robert Kellogg. 2006. The Nature of Narrative. Fortieth Anniversary Edition Revised and Expanded. New York: Oxford University Press.

Schottroff, Luise. 1998. The Samaritan Woman and the Notion of Sexuality in the Fourth Gospel. In What is John: Literary and Social Readings of the Fourth Gospel. Edited by Fernando Segovia. Atlanta: Scholars Press, vol. 2, pp. 157-81.

Scott, Bernard Brandon. 1989. Hear Then the Parable: A Commentary on the Parables of Jesus. Minneapolis: Fortress Press. 
Sellew, Phillip. 1992. Interior Monologue as a Narrative Device in the Parables of Jesus. Journal of Biblical Literature 111: 239-53. [CrossRef]

Sheeley, Steven M. 1992. Narrative Asides in Luke-Acts. Journal for the Study of the New Testament Supplement Series 72. Sheffield: JSOT Press.

Shen, Dan. 2013. Unreliability. In The Living Handbook of Narratology. Edited by Peter Hühn, Jan Christoph Meister, John Pier and Wolf Schmid. Hamburg: Hamburg University. Available online: http://www.lhn.unihamburg.de/article/unreliability (accessed on 18 March 2019).

Shepherd, Tom. 1995. The Narrative Function of Markan Intercalation. New Testament Studies 41: 522-40. [CrossRef]

Sheridan, Ruth. 2016. Persuasion. In How John Works: Storytelling in the Fourth Gospel. Edited by Douglas Estes and Ruth Sheridan. Atlanta: SBL Press, pp. 205-23.

Shklovsky, Victor. 2012. Art as Technique. In Russian Formalist Criticism: Four Essays, 2nd ed. Translated by Lee T. Lemon, and Marion J. Reis. Lincoln: University of Nebraska Press, pp. 3-24. First published 1917.

Skinner, Christopher W., ed. 2013. Characters and Characterization in the Gospel of John. Library of New Testament Studies 461. London: Bloomsbury T \& T Clark.

Skinner, Christopher W., and Matthew Ryan Hauge, eds. 2014. Character Studies and the Gospel of Mark. Library of New Testament Studies 483. London: Bloomsbury T \& T Clark.

Smith, Stephen H. 1996. A Lion with Wings: A Narrative-Critical Approach to Mark's Gospel. The Biblical Seminar 38. Sheffield: Sheffield Academic Press.

Starobinski, Jean. 1973. The Struggle with Legion: A Literary Analysis of Mark 5:1-20. New Literary History: A Journal of Theory and Interpretation 4: 331-56. [CrossRef]

Sternberg, Meir. 1978. Expositional Modes and Temporal Ordering in Fiction. Baltimore: Johns Hopkins University Press.

Suleiman, Susan R., and Inge Crossman, eds. 1980. The Reader in the Text: Essays on Audience and Interpretation. Princeton: Princeton University Press.

Tannehill, Robert. 1975. The Sword of His Mouth: Forceful and Imaginative Language in Synoptic Sayings. Semeia Supplements. Philadelphia: Fortress Press.

Taylor, Vincent. 1960. The Gospel according to St. Mark, 2nd ed. London: Macmillan.

Todorov, Tzvetan. 1969. Grammaire du Décaméron. The Hague: Moulton.

Tolmie, D. Francois. 1999. Narratology and Biblical Narratives: A Practical Guide. San Francisco: International Scholars Publications.

Tompkins, Jane P., ed. 1980. Reader-Response Criticism: From Formalism to Post-Structuralism. Baltimore: Johns Hopkins University Press.

Trible, Phyllis. 1978. God and the Rhetoric of Sexuality. Overtures to Biblical Theology. Philadelphia: Fortress Press.

Tull, Patricia K. 2013. Narrative Criticism and Narrative Hermeneutics. In The Oxford Encyclopedia of Biblical Interpretation. Edited by Stephen L. McKenzie. New York: Oxford University Press, vol. 2, pp. 37-46.

Uspensky, Boris. 1973. A Poetics of Composition: The Structure of the Artistic Text and Typology of Compositional Form. Translated by Valentina Zavarin, and Susan Wittig. Berkeley: University of California Press.

Via, Dan Otto, Jr. 1967. The Parables: Their Literary and Existential Dimension. Philadelphia: Fortress Press.

Whitenton, Michael R. 2016. The Dissembler of John 3: A Cognitive and Rhetorical Approach to the Characterization of Nicodemus. Journal of Biblical Literature 135: 141-58.

Wimsatt, W. K., Jr., and Monroe C. Beardsley. 1954. The Verbal Icon: Studies in the Meaning of Poetry. Lexington: University Press of Kentucky.

Yamasaki, Gary. 2007. Watching a Biblical Narrative: Point of View in Biblical Exegesis. London: T \& T Clark.

(c) 2019 by the author. Licensee MDPI, Basel, Switzerland. This article is an open access article distributed under the terms and conditions of the Creative Commons Attribution (CC BY) license (http:/ / creativecommons.org/licenses/by/4.0/). 